\title{
The impact of Hurricanes on the value of commercial real estate
}

\author{
Jeffrey D. Fisher ${ }^{1}$. Sara R. Rutledge ${ }^{2}$ (1)
}

Published online: 22 March 2021

(c) The Author(s) 2021

\begin{abstract}
Commercial real estate investors prefer coastal, gateway, markets for liquidity, demand density, and durable returns. Yet, these areas are more vulnerable to the effects of climate change from more intense and frequent weather events such as hurricanes and typhoons as well as to gradual changes such as sea-level rise. Recognition is growing of the risks that these events pose to investment performance, but little is known about how this risk has impacted property values and returns when an event such as a hurricane occurs. This is the first study to analyze the impact on property values and returns from hurricanes causing the most significant damage by value over the past 30-plus years throughout the nation. Using individual property data from the National Council of Real Estate Investment Fiduciaries database, we find a significant impact on the value and rates of return, after accounting for any additional capital expenditures for repairs, for properties that are in areas impacted by a hurricane, relative to areas that were not impacted by a hurricane. These impacts vary by property type and can last for several years after the hurricane hit land in the area.
\end{abstract}

Keywords Real estate $\cdot$ Investment $\cdot$ Property risk $\cdot$ Hurricane $\cdot$ Climate change

\section{Introduction}

Investor preferences for coastal, gateway, markets mean that many assets held by real estate investors are in cities more vulnerable to the effects of climate change. These effects range from more intense and frequent weather events such as hurricanes and typhoons to gradual changes such as sealevel rise. Recognition is growing of the risks that these events pose to investment performance. Recent weather events caused significant physical damages to properties and infrastructure. In 2017, the year Hurricanes Harvey and Maria hit the United States and storms battered northern and central Europe, insurers paid out a record $\$ 135$ billion globally for damage caused by storms and natural disasters. This figure does not represent actual damages, which in the United States alone which equaled $\$ 307$ billion, according

Sara R. Rutledge

srrutledge@gmail.com

Jeffrey D. Fisher

jfishe48@jhu.edu

1 Homer Hoyt Institute, 760 US Highway 1, Suite 300, North Palm Beach, FL 33408, USA

2 SRR Consulting, 1620 Fowler Avenue, Evanston, IL 60201, USA to National Oceanic and Atmospheric Administration estimates.

For leading real estate investors and investment managers, the need to understand and develop strategies to address climate-related risks needs to be understood and prioritized.

Yet little is known about how this risk has impacted property values and returns when an event such as a hurricane occurs. The impact extends beyond the direct damage to the property. An increase in the perceived risk of hurricanes can result in a reluctance by institutional investors to add capital to that area, which can lead to a negative impact on property values and returns well after the hurricane to all properties and property types in the area that was impacted by a hurricane. This is the first study to analyze the impact on property values and returns from all the significant hurricanes that occurred over the past 30-plus years throughout the nation. We find that there has been a significant impact on the value and rates of return, after accounting for any additional capital expenditures for repairs, for properties that are in areas impacted by a hurricane relative to areas that were not impacted by a hurricane. This can last for several years after the hurricane hit land in the area. 


\section{Literature review}

The real estate literature is limited on this topic. There is research exploring the impact of natural disasters on residential property market activity and valuation. This research largely covers single-family housing with limited coverage on multifamily properties. Although other commercial property types are rarely considered, these studies provide three common themes: (1) natural disasters negatively impact real estate, (2) increased expectations of natural disasters amplify this negative impact, and (3) negative real estate impacts fade over time.

The literature, as in Graham and Hall (2001), Bliech (2003), and Morgan (2007), establishes that natural disasters have a negative impact on real estate pricing and/or values. Graham and Hall (2001), in a study of multiple hurricanes making landfall in the Wilmington area of North Carolina, find that residential property values face increasingly negative impacts from successive hurricanes. Also relevant to this paper is that Graham and Hall (2001) used factors in their model to control for other impacts on housing values, such as location and economic conditions.

Morgan (2007) researched Hurricane Ivan's 2004 impacts on risk perceptions and housing values in Santa Rosa County, Florida. The author identifies reduced home sale prices for properties in high-risk flood areas after the hurricane. Housing in these floodplains commanded a premium relative to other houses in the county prior to the hurricane, as federally insured areas in desirable waterfront locations. It is noteworthy that the observed $15 \%$ post-Ivan reduction in prices did not eliminate the home price premium in floodplains.

Turning to a different type of natural disaster, Bleich (2003) researched the impact of the 1994 Northridge Earthquake on the Los Angeles multifamily property market. A negative impact on values was identified using capitalization rates, which rose overall. However, multifamily capitalization rates increased the most near the earthquake's epicenter and areas not experiencing damage did not have valuation impacts.

The Graham and Hall (2001) findings of increasingly negative impacts on housing values led the authors to conclude that a period of unprecedented hurricane activity increased the market expectations of catastrophic risk, contributing to market instability. Housing in the Wilmington area of North Carolina was studied after landfall by hurricanes Bertha and Fran in 1996, Bonnie 1998, and Floyd 1999. Results revealed limited effects after the 1996 storms, but successively more extreme and immediate negative consequences on real estate values were observed after Bonnie and Fran. This structural shift in the housing market was identified as largely related to recurring hurricane landfalls and increased perceptions of catastrophic risk.

Morgan (2007) also address the topic of risk perceptions before after Hurricane Ivan. The author's focus was on how subsidized insurance premiums could create a market imbalance by reducing expected flood losses and perceived risks associated with living in floodplain areas. In addition to the findings on Santa Rosa County, Florida home prices declines after the hurricane, the author observed that damage from Ivan led to significant changes in flood insurance premiums. The research estimated pre- and post-hurricane capitalized values of flood insurance premiums to conclude that expected flood losses in the county rose by $75 \%$ after Ivan, amplifying the perceived risk of properties located in these floodplains.

The importance to this study lies in the increasing frequency of large and powerful hurricanes due to the changing global climate. Highlighting this shift in frequency and intensity is the fact that 14 of the top 20 costliest mainland United States tropical cyclones have occurred from 2000 to $2017,{ }^{1}$ two of which made landfall in 2017-Harvey (tied with Katrina 2005 for costliest storm) and Irma (ranked fifth).

Graham et al. (2007) expanded upon Graham and Hall's earlier research to study the duration of negative impacts to housing values following landfall of a hurricane. The authors' findings support the same pattern of increasing home price declines with each successive hurricane. Then, their research reveals a tempering of this trend with a price recovery and the return to pre-storm market stability over the 3 years following the last major hurricane strike.

Similarly, Salter and King (2009) found that an unannounced event can cause an overreaction that the market will correct via pricing adjustments, although information inefficiencies can create a lag in this correction. Their research covered the post-Hurricane Katrina housing market in Hattiesburg, Mississippi-an area on the periphery of the storm's impact. This study of a market less damaged, but adjacent to more devastated areas, yields additional information about the complexity of hurricane impacts on real estate pricing and liquidity. The supply/demand balance for housing tightened due an increase in housing demand from people displaced by the storm and a reduction, at least temporarily, in supply from storm damage. Thus, the market correction is related to the timing for bringing supply back online through repairs or new construction.

In the Bleich (2003) earthquake study, proximity to the natural disaster was found to be a factor in the real estate

\footnotetext{
${ }^{1}$ National Hurricane Center, Costliest U.S. tropical cyclone tables updated, Table 3a. https://www.nhc.noaa.gov/news/UpdatedCostliest. pdf.
} 
effects with first year impacts correlated to the epicenter and areas with the high concentrations of damage. The author also found these impacts to be temporary because, by the third year of the analysis, negative effects were not significant. There were, however, lingering effects on values for older multifamily buildings with architectural styles that proved to be less resistant to earthquakes. On the flipside, Simmons et al. (2002) find that risk mitigation factors in a Gulf Coast city to protect homes from hurricane damage enhanced home values.

This paper addresses all three themes by researching the impact on real estate values from the most catastrophic hurricanes over the years after these storms. Most importantly, this paper fills a significant gap in the literature by examining these impacts on commercial real estate values.

\section{Data}

The data for this study come from the National Council of Real Estate Investment Fiduciaries (NCREIF). NCREIF is a non-profit, membership organization of the institutional investment managers that invest in U.S. commercial real estate on behalf of their clients, including high net worth individuals, pension funds, and endowments. NCREIF was formed to create benchmarks to track the performance of commercial real estate as an asset class.

The NCREIF Property Index (NPI) begins in 1978 and includes quarterly data on five major property types: apartment, hotel, industrial, office, and retail. The quarterly property data are provided directly to NCREIF from the accounting of individual property performance by their investment management membership. Data on income and capital expenditures are provided on the properties each quarter in addition to appraised property values, because managers use current value accounting for performance reporting to investors. Investment manager members also report data on other property types, such as self-storage and senior housing, and these data are included in the complete property database available for research use. As of fourth quarter 2019, the NPI includes 8262 properties with an aggregate market value of $\$ 658.4$ billion, and the complete property database includes 10,213 properties valued at $\$ 741.2$ billion. The historical database has information on nearly 800,000 properties, including those that have been sold over time.

For this study, individual property data were used from 1989 to 2019, which spans the period the major hurricanes occurred that were included in this study. Property types included office, retail, apartment, industrial, and hotel, spanning the entire U.S. There were over 400,000 property observations (cross sectional and time series) depending on the panel regression used, as discussed below. The data cover both areas that were impacted by hurricanes and areas that were not impacted either during the same time as a hurricane, or ever impacted by a hurricane, to capture the relative impact of hurricanes on property values and returns.

Nineteen hurricanes making U.S. landfall were included, as summarized in Table 1. The table lists the hurricane's name, landfall date, estimated damage, and impacted locations. The NHC's most recent list of the costliest U.S. tropical cyclones (updated 2018) was used to identify a list of major hurricanes. The NHC damage estimates include insured and uninsured losses and are estimated using source data from Federal Emergency Management Agency, U.S. Department of Agriculture, National Interagency Fire Center, U.S. Army Corps of Engineers, state emergency management agencies, state and regional climate centers, and insurance industry estimates. This broad assessment of damages reveals a list of storms most likely to affect commercial real estate. The fifteenth costliest hurricane on the NHC list (Allison) made landfall as a tropical storm. Given its ranking on the list and impact to a major real estate market (Houston), this storm was included in the analysis.

The Census-defined core-based statistical areas (CBSAs) and divisions impacted by these hurricanes were determined by reviewing detailed cyclone reports from the U.S. Department of Commerce National Oceanic and Atmospheric Administration National Hurricane Center (NHC). CBSAs are U.S. geographic areas defined by the Office of Management and Budget, and consist of one or more counties (or equivalents) anchored by an urban center of at least 10,000 people plus adjacent counties that are socioeconomically tied to the urban center by commuting. Larger CBSAs by population may have multiple divisions within them. If a CBSA has a division, we use the division instead of the entire CBSA.

The CBSAs and divisions in this analysis were selected based upon each hurricane's tracked path from landfall until the storm was no longer categorized as a hurricane per NHC reporting. In some cases, a CBSA or division identified as being impacted by a hurricane did not have property data in the NCREIF database and had to be excluded from this analysis. $^{2}$

\section{Methodology}

This study is designed to capture the impact of a hurricane on all the properties in CBSAs and/or divisions. We measure the impact of a hurricane on a CBSA or division that had a

\footnotetext{
${ }^{2}$ Locations impacted by hurricanes without corresponding NCREIF data include: Dover, DE (Hurricane Isabel), Lafayette, LA (Hurricane Gustav), Lake Charles, LA (Hurricanes Harvey and Rita), and Morehead City, NC (Hurricanes Irene and Floyd).
} 
Table 1 Major U.S. Hurricanes

\begin{tabular}{|c|c|c|c|c|}
\hline Hurricane name & U.S. Landfall quarter & $\begin{array}{l}\text { NHC damage est. } \\
\text { (billions, nominal) }\end{array}$ & Impacted CBSAs and divisions & \\
\hline Allison & 2Q 2001 & $\$ 8.5$ & Houston-The Woodlands, TX & \\
\hline Andrew & 3Q 1992 & $\$ 27.0$ & $\begin{array}{l}\text { Baton Rouge, LA } \\
\text { Fort Lauderdale, FL } \\
\text { Miami, FL }\end{array}$ & $\begin{array}{l}\text { New Orleans, LA } \\
\text { West Palm Beach, FL }\end{array}$ \\
\hline Charley & 3Q 2004 & $\$ 16.0$ & $\begin{array}{l}\text { Daytona Beach, FL } \\
\text { Fort Meyers, FL } \\
\text { Myrtle Beach, SC }\end{array}$ & $\begin{array}{l}\text { Orlando, FL } \\
\text { Tampa, FL }\end{array}$ \\
\hline Floyd & 3Q 1999 & $\$ 6.5$ & Virginia Beach-Norfolk, VA & Wilmington, $\mathrm{NC}$ \\
\hline Fran & 3Q 1996 & $\$ 5.0$ & $\begin{array}{l}\text { Myrtle Beach, SC } \\
\text { Raleigh-Durham, NC }\end{array}$ & $\begin{array}{l}\text { Washington, DC } \\
\text { Wilmington, DE }\end{array}$ \\
\hline Frances & 3Q 2004 & $\$ 9.8$ & $\begin{array}{l}\text { Daytona Beach, FL } \\
\text { Orlando, FL } \\
\text { Port St. Lucie, FL }\end{array}$ & $\begin{array}{l}\text { Tampa, FL } \\
\text { West Palm Beach, FL }\end{array}$ \\
\hline Gustav & 3Q 2008 & $\$ 6.0$ & Baton Rouge, LA & New Orleans, LA \\
\hline Harvey & 3Q 2017 & $\$ 125.0$ & $\begin{array}{l}\text { Houston-The Woodlands, TX } \\
\text { Beaumont-Port Arthur, TX }\end{array}$ & $\begin{array}{l}\text { Corpus Christie, TX } \\
\text { Victoria-Port Lavaca, } \\
\text { TX }\end{array}$ \\
\hline Hugo & 3Q 1989 & $\$ 7.0$ & $\begin{array}{l}\text { Charleston, SC } \\
\text { Charlotte, NC }\end{array}$ & $\begin{array}{l}\text { Columbia, SC } \\
\text { Myrtle Beach, SC }\end{array}$ \\
\hline Ike & 3Q 2008 & $\$ 30.0$ & Houston-The Woodlands, TX & $\begin{array}{l}\text { Beaumont-Port Arthur, } \\
\text { TX }\end{array}$ \\
\hline Irene & 3Q 2011 & $\$ 13.5$ & $\begin{array}{l}\text { Atlantic City, NJ } \\
\text { Jacksonville, NC } \\
\text { Nassau Co-Suffolk Co, NY }\end{array}$ & $\begin{array}{l}\text { New York, NY } \\
\text { Virginia Beach-Nor- } \\
\text { folk, VA }\end{array}$ \\
\hline Irma & 3Q 2017 & $\$ 50.0$ & $\begin{array}{l}\text { Fort Lauderdale, FL } \\
\text { Fort Meyers, FL } \\
\text { Gainesville, FL } \\
\text { Miami, FL } \\
\text { Naples, FL }\end{array}$ & $\begin{array}{l}\text { Orlando, FL } \\
\text { Port St. Lucie, FL } \\
\text { Savannah, GA } \\
\text { Tampa, FL } \\
\text { West Palm Beach, FL }\end{array}$ \\
\hline Isabel & 3Q 2003 & $\$ 5.5$ & $\begin{array}{l}\text { Baltimore, MD } \\
\text { Virginia Beach-Norfolk, VA }\end{array}$ & $\begin{array}{l}\text { Washington, DC } \\
\text { Wilmington, DE }\end{array}$ \\
\hline Jeanne & 3Q 2004 & $\$ 7.5$ & $\begin{array}{l}\text { Daytona Beach, FL } \\
\text { Orlando, FL } \\
\text { Port St. Lucie, FL }\end{array}$ & $\begin{array}{l}\text { Tampa, FL } \\
\text { West Palm Beach, FL }\end{array}$ \\
\hline Katrina & 3Q 2005 & $\$ 125.0$ & New Orleans, LA & Gulfport, MS \\
\hline Matthew & 4Q 2016 & $\$ 10.0$ & $\begin{array}{l}\text { Charleston, SC } \\
\text { Hilton Head, SC } \\
\text { Jacksonville, FL } \\
\text { Jacksonville, NC }\end{array}$ & $\begin{array}{l}\text { Myrtle Beach, SC } \\
\text { Savannah, GA } \\
\text { Wilmington, NC }\end{array}$ \\
\hline Rita & 3Q 2005 & $\$ 18.5$ & Houston-The Woodlands, TX & $\begin{array}{l}\text { Beaumont-Port Arthur, } \\
\text { TX }\end{array}$ \\
\hline Sandy & 4Q 2012 & $\$ 65.0$ & $\begin{array}{l}\text { Atlantic City, NJ } \\
\text { Camden, NJ } \\
\text { Nassau Co-Suffolk Co, NY }\end{array}$ & $\begin{array}{l}\text { New York, NY } \\
\text { Newark, NJ } \\
\text { Ocean City, NJ }\end{array}$ \\
\hline Wilma & 4Q 2005 & $\$ 19.0$ & $\begin{array}{l}\text { Fort Lauderdale, FL } \\
\text { Fort Meyers, FL }\end{array}$ & $\begin{array}{l}\text { Miami, FL } \\
\text { West Palm Beach, FL }\end{array}$ \\
\hline
\end{tabular}

hurricane whether it was physically damaged or not. Institutional investors can choose to allocate less or no capital to areas that have been impacted by a hurricane and tenants can be more reluctant to sign leases in those areas. All these factors can impact occupancy, risk premiums and property values after a hurricane-especially if the risk of future hurricanes is perceived to have increased due to climate change.

Panel regression using cross-sectional and time-series data methodology were estimated. For every property and for every quarter, we calculated the cumulative change in 
Table 2 Variable summary

\begin{tabular}{|c|c|c|}
\hline Variable & Type & Description \\
\hline Property value & Dependent & Quarterly appraisal-based property market value per NCREIF \\
\hline Property total return & Dependent & Quarterly property investment return from income and appreciation per NCREIF \\
\hline Property capital return & Dependent & Quarterly property return from market appreciation per NCREIF \\
\hline HurricaneQtr & Dummy & $\begin{array}{l}\text { Indicator is } 1 \text { for properties in a location (CBSA or Division) impacted by a major hurricane in during the } \\
\text { quarter }\end{array}$ \\
\hline CBSAorDiv & Dummy & Dummy variables for all locations (CBSA or Division) to control for fixed effects \\
\hline yyyyq & Dummy & Dummy variables for each quarterly period to control for property market conditions over time \\
\hline Square feet (sqft) & Independent & Property size in square feet per NCREIF \\
\hline Sqft2 & Independent & Squared property size to allow for nonlinear relationship to property performance \\
\hline Age & Independent & Property age in quarters from completion date per NCREIF \\
\hline Age2 & Independent & Squared property age in quarters to allow for nonlinear relationship to property performance \\
\hline Percentleased & Independent & $\begin{array}{l}\text { Leased square feet in a property as a share of the property's total square feet for the quarter before the } \\
\text { hurricane }\end{array}$ \\
\hline Apartmenthq & Interaction & Interaction dummy variable with an indicator of 1 for apartment properties in a hurricane quarter \\
\hline Industrialhq & Interaction & Interaction dummy variable with an indicator of 1 for industrial properties in a hurricane quarter \\
\hline Officehq & Interaction & Interaction dummy variable with an indicator of 1 for office properties in a hurricane quarter \\
\hline Retailhq & Interaction & Interaction dummy variable with an indicator of 1 for retail properties in a hurricane quarter \\
\hline
\end{tabular}

value and cumulative return over the next $1,2,3,4$, and 5 -year periods. This process creates the dependent variables that are used in the various models. For example, one model will examine how the value changed over the four quarters after the hurricane landfall quarter. This change in value will be calculated for all properties whether they were in the CBSA or division impacted by the hurricane or not so we can compare the relative change in value.

Similar dependent variables were created for the capital return (or appreciation), which is a measure of the change in value net of capital expenditures (capex) and for the total return, which is the combination of income and capital returns. Appreciation by itself was used in addition to the change in value because properties impacted by hurricanes might have incurred more capex for repairs than properties not impacted by a hurricane. This allows us to consider that some of the loss in value from the hurricane may have been restored by additional capex being spent on the property.

To determine whether a hurricane impacted the value change and other measures discussed above after the hurricane, a dummy variable was used to indicate if the property is in the CBSA or division impacted by one of the hurricanes during the quarter of the hurricane. The dummy variable is 1 if the property is in the CBSA or division where there was a hurricane during that quarter. Otherwise, the dummy variable was zero. Thus, the coefficient of this variable indicates the marginal impact of a property being in the area of the hurricane in the quarters after the occurrence of the hurricane.
To control for the fixed effects of different locations in the U.S., dummy variables were also created for each CBSA or division regardless of whether it was impacted by a hurricane. These are strictly cross-sectional dummy variables.

Similarly, we created dummy variables for each quarter to control for changes in market conditions over time. The coefficients of these quarterly dummy variables could be used to create a national price index. As a check on the validity of the model, we verified that this price index essentially replicated the equal weighted version of the NCREIF Property Index.

Table 3 Regression results for cumulative property value change, 8 quarters after hurricane

\begin{tabular}{lllr}
\hline Variable & Coefficient & Stnd. error & \multicolumn{1}{c}{$t$-stat } \\
\hline Constant & 0.12153350 & 0.07604170 & 1.60 \\
Sqft & 0.00000001 & 0.00000000 & 9.07 \\
Sqft2 & 0.00000000 & 0.00000000 & -6.09 \\
Age & 0.00034200 & 0.00003520 & 9.72 \\
Age2 & -0.00000015 & 0.00000002 & -8.47 \\
Percentleased & 0.05253790 & 0.00391590 & 13.42 \\
HurricaneQtr & -0.25885300 & 0.07441150 & -3.48 \\
Observations & 334,132 & & \\
MSE & 0.09697279 & & \\
$F$ test (probability) & 0.00000000 & & \\
\hline
\end{tabular}


Figure 1 Cumulative property value change for quarters after hurricanes

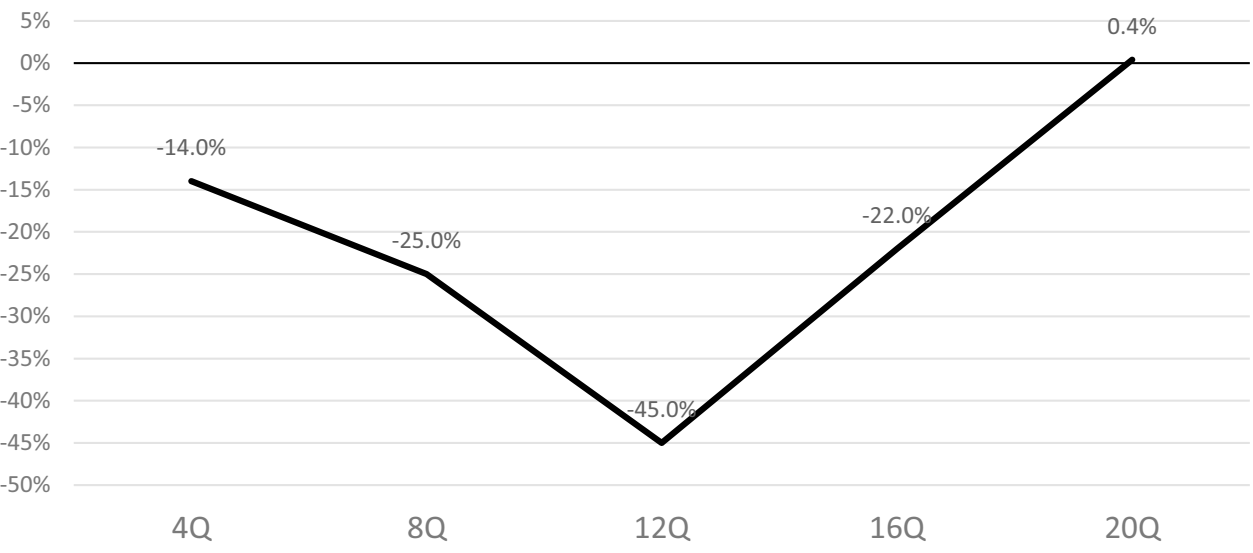

Table 4 Regression results for cumulative property value change with property-type interaction terms, 8 quarters after hurricane

\begin{tabular}{lllr}
\hline Variable & Coefficient & Stnd. error & \multicolumn{1}{c}{$t$-stat } \\
\hline Constant & 0.12376260 & 0.07602000 & 1.63 \\
Sqft & 0.00000001 & 0.00000000 & 8.93 \\
Sqft2 & 0.00000000 & 0.00000000 & -6.05 \\
Age & 0.00035140 & 0.00003520 & 9.97 \\
Age, squared & -0.00000015 & 0.00000002 & -8.79 \\
Percent leased & 0.04967120 & 0.00393010 & 12.64 \\
HurricaneQtr & -0.30781210 & 0.07508430 & -4.10 \\
Apartmenthq & 0.04246640 & 0.01064470 & 3.99 \\
Industrialhq & 0.07234580 & 0.01050950 & 6.88 \\
Officehq & 0.03552060 & 0.01061390 & 3.35 \\
Retailhq & 0.04477270 & 0.01074850 & 4.17 \\
Observations & 334,132 & & \\
MSE & 0.09697279 & & \\
$F$ test (probability) & 0.00000000 & & \\
\hline
\end{tabular}

Independent variables were also used to control for the fact that the change in value, and returns for a property tend to vary with the size (measured in square feet) and age (measured in quarters from property completion date) of the property. These impacts tend to be nonlinear. Thus, we included variables for the property square footage, square footage squared, property age, and age squared. If the relationship turned out to be linear, the coefficients of these squared variables would be insignificant. We also included the occupancy of each property as of the quarter prior to the hurricane as an independent variable.

Finally, we created interaction dummy variables to indicate what the property type is for a property that was impacted by a hurricane. For example, the office interaction dummy variable was 1 if it was an office property with the hurricane dummy of 1 in the area of a hurricane as of the quarter of a hurricane. Hotel properties were the omitted dummy variable. The coefficient of this dummy variable indicates how each property type was impacted relative to the impact on hotels.

The variables described in this section are summarized in Table 2 above. Regressions were run separately for each of the time periods after the hurricane (1 year after, 2 years after, etc.) and for each of the different dependent variables (price change, capital return, and total return). The results are discussed in the next section.

\section{Results}

Table 3 shows the results of one of the regressions of the impact of hurricanes on the cumulative change in value eight quarters after the hurricane. There were 334,132 propertyquarter observations. The cofficients on the dummy variables used for each location (CBSA or Division) and quarter are not shown below, but are provided in the Appendix.

The estimated coefficients on the variables for square feet, square feet squared, age, and age squared are all highly significant, as is the occupancy at the time of the hurricane. The hurricane dummy variable indicates that the property was in the CBSA or division impacted by a hurricane on the quarter the hurricane made U.S. landfall. It indicates how much this affected the cumulative change in value over the following eight quarters relative to how the properties performed that were not in the areas impacted by the hurricane. In this model, the property-type interaction variables are omitted so we can get an indication of the overall impact on a portfolio of all property types. The results suggest that over the eight quarters following the hurricane quarter, property values increased by $25.9 \%$ less than properties not impacted by a hurricane, or $3.2 \%$ per quarter.

The same regression was run for 1, 3, 4, and 5-year time periods following hurricane landfall for all property types combined. Figure 1 is a graph of the impact on value change over time. We see that the impact on value 
Table 5 Cumulative value change by property type, from 1 to 5 years after hurricane

\begin{tabular}{lccccc}
\hline Property type & \multicolumn{6}{l}{ Quarters after Hurricane } \\
\cline { 2 - 6 } & 4Q $(\%)$ & $8 \mathrm{Q}(\%)$ & 12Q $(\%)$ & 16Q $(\%)$ & 20Q $(\%)$ \\
\hline Hotel & -14.5 & -30.0 & -41.0 & -21.0 & -2.0 \\
Apartment & -13.8 & -26.0 & -41.7 & -19.0 & 5.0 \\
Industrial & -12.4 & -23.0 & -46.0 & -23.0 & -1.6 \\
Office & -15.5 & -26.5 & -45.0 & -18.0 & -3.5 \\
Retail & -13.0 & -25.5 & -42.0 & -19.0 & 5.0 \\
\hline
\end{tabular}

Table 6 Cumulative appreciation change by property type, from 1 to 5 years after hurricane

\begin{tabular}{lllllc}
\hline Property type & \multicolumn{6}{l}{ Quarters after Hurricane } \\
\cline { 2 - 6 } & 4Q $(\%)$ & $8 \mathrm{Q}(\%)$ & 12Q $(\%)$ & 16Q $(\%)$ & 20Q $(\%)$ \\
\hline Hotel & -11.0 & -27.3 & -43.3 & -24.0 & -7.4 \\
Apartment & -7.1 & -24.9 & -39.8 & -14.2 & 6.2 \\
Industrial & -8.4 & -24.9 & -46.2 & -20.4 & -3.4 \\
Office & -9.9 & -27.8 & -47.3 & -25.1 & -7.4 \\
Retail & -8.7 & -27.4 & -41.9 & -16.3 & 5.5 \\
\hline
\end{tabular}

Figure 2 Cumulative value change for quarters after hurricanes by property type

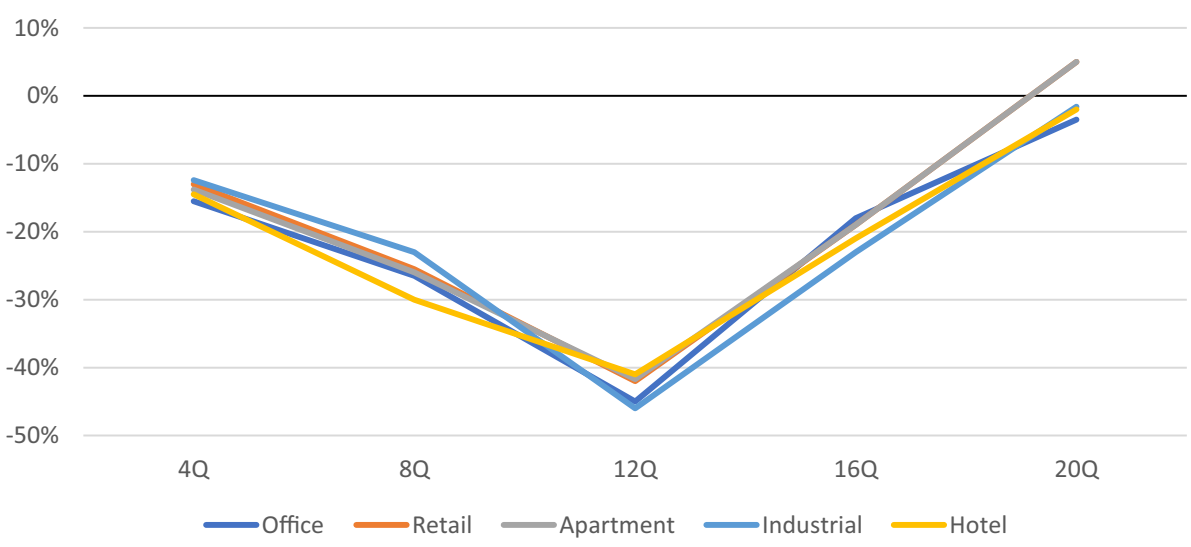

continues to be negative until 3 years (or 12 quarters) after the hurricane, and then, the impact starts to dissipate with values recovering 5 years (or 20 quarters) after the hurricane.

Table 4 shows the regression results when the propertytype interaction dummies are added. For example, the apartment dummy is 1 if there is a hurricane during the quarter in that CBSA or division and the property is an apartment. The impact of a hurricane is then found by adding the coefficient from the hurricane quarter dummy to the interaction dummy for each property type. Since hotels are the omitted property-type interaction variable, the impact on hotels is just the coefficient of the hurricane quarter dummy. ${ }^{3}$

The hurricane quarter dummy variable (as well as each of the property-type interaction variables) is statistically significant. The positive coefficients for the property-type dummies indicate that the impact of the hurricane is less for that property type than for the omitted hotel interaction variable. However,

\footnotetext{
${ }^{3}$ An alternative approach is to leave out the hurricane quarter dummy when including the property-type interaction variables. In this case, the property-type interaction variables would capture the full impact of the hurricane on that property type. There would be no need to leave out a property type because the "omitted variable" would be when there is no hurricane that quarter in a CBSA or division. Using this approach resulted in essentially the same results for the impact of the hurricane on each property type.
}

the total impact is still negative when the coefficient for the interaction dummy is added to the coefficient of the hurricane quarter dummy. Table 5 shows the results when regressions are run for 1 to 5 years, and Fig. 2 graphs the results.

We have shown the impact of hurricanes on the cumulative change in value after the ocurrance of a hurricane on each property type. This is the impact on all properties in the area of the hurricane regardless of whether they were actually physically damaged. Those properties that were physically damaged may have had repairs after the hurricane that would restore the loss in value due to the damage-but not any impact due to less demand by tenants and investors for properties in the hurricane impacted area.

To control for the capital expenditure on repairs, we calculated the cumulative capital return for each property for 1 , $2,3,4$, and 5 years after the hurricane. The capital return is the change in value net of capital expenditures. That is, if the value increased only because of capital expenditures, the capital return would be zero. The regressions discussed above were repeated using the cumulative capital return as the dependent variable. The results are shown in Table 6 and Fig. 3 .

Finally, we examined the impact of hurricanes on the total return that investors would receive from income and capital appreciation net of capex. In this case, the coefficients indicate how much the return is impacted relative to the NCREIF Property Index (NPI) in areas not impacted by a hurricane. 
Figure 3 Cumulative appreciation change for quarters after hurricanes by property type

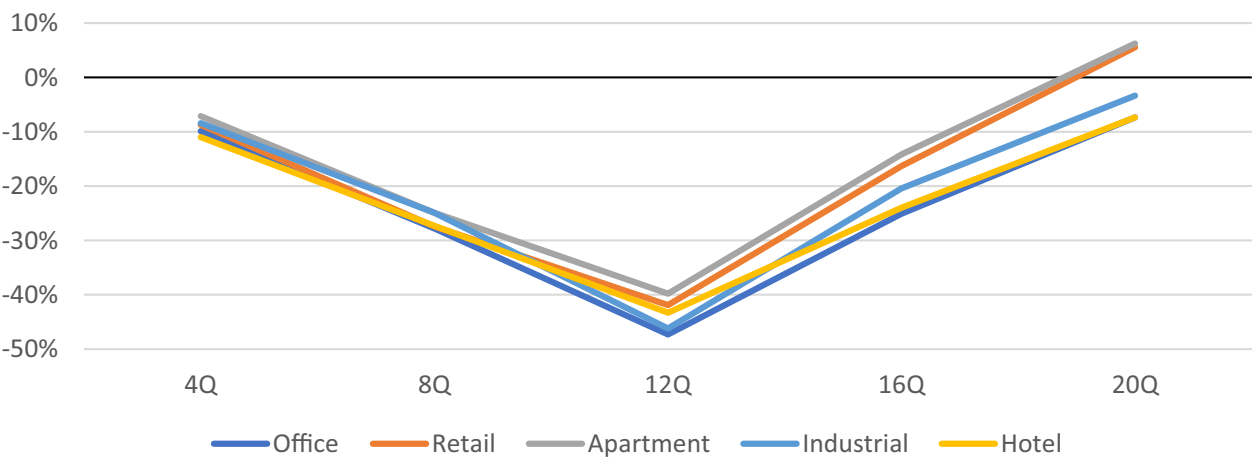

Table 7 Cumulative change in total return by property type, from 1 to 5 years after hurricane

\begin{tabular}{lccccc}
\hline Property type & \multicolumn{6}{l}{ Quarters after Hurricane } \\
\cline { 2 - 6 } & 4Q $(\%)$ & $8 \mathrm{Q}(\%)$ & 12Q $(\%)$ & 16Q $(\%)$ & 20Q $(\%)$ \\
\hline Hotel & -5.0 & -24.5 & -43.8 & -7.0 & 5.3 \\
Apartment & -6.1 & -31.5 & -52.2 & -11.0 & 4.3 \\
Industrial & -5.9 & -28.5 & -54.2 & -12.0 & -0.7 \\
Office & -7.4 & -32.0 & -56.8 & -19.4 & -6.7 \\
Retail & -6.7 & -32.5 & -51.7 & -9.4 & 7.3 \\
\hline
\end{tabular}

The cumulative return was calculated from 1 to 5 years after the hurricane. The results are shown in Table 7 and Fig. 4.

\section{Conclusion}

This paper examined the impact of hurricanes on properties owned by institutional investors. It is the first study to examine all the significant hurricanes that have occurred since 1988, which include 19 storms that impacted different areas of the U.S. After controlling for property size, age, location, time (market conditions), and occupancy, we find that hurricanes appear to have a significant impact on property values, appreciation (net of capex), and total return.

The impact on all three measures peaked 3 years after hurricane landfall and then began to dissipate over the following 2 years. Five years after a major hurricane, apartment and retail properties had recovered, but office, hotel, and industrial still experienced a cumulative negative impact on the capital return.

The results of this study are important for investors deciding whether to allocate additional capital—especially if the perceived risk of additional hurricanes in an area is increasing due to climate change. The impact on property values and returns that we found go beyond any impact due to physical damage to the properties. The loss in value appears to last up to 5 years after the hurricane makes landfall, and is likely a result of higher risk premiums and lower tenant demand after the occurrence of a hurricane.
Figure 4 Cumulative total return change for quarters after Hurricanes by property type

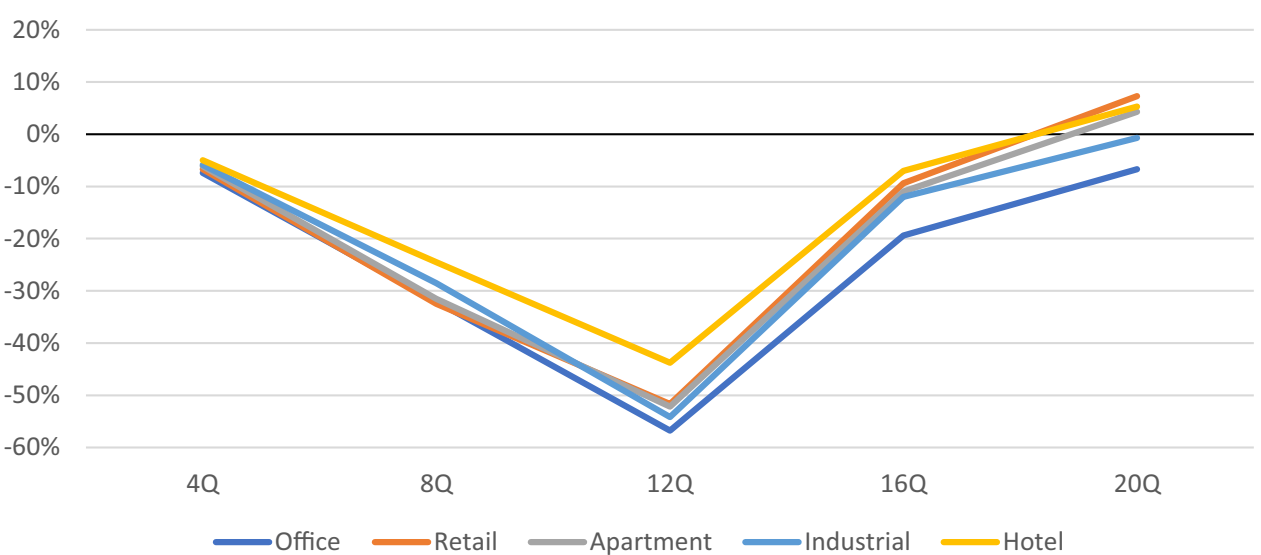




\section{Appendix}

Quarter and Location Dummy Variable Regression Results, without (1) and with (2) Interaction Dummy Variables

\begin{tabular}{|c|c|c|c|c|}
\hline $\begin{array}{l}\text { Dummy vari- } \\
\text { able }\end{array}$ & Coefficient (1) & $t$-stat (1) & Coefficient (2) & $t$-stat (2) \\
\hline yyyyq_19852 & 0.00562370 & 0.06 & 0.00568200 & 0.06 \\
\hline yyyyq_19853 & 0.01743420 & 0.17 & 0.01750870 & 0.17 \\
\hline yyyyq_19854 & -0.03822030 & -0.38 & -0.03812980 & -0.38 \\
\hline ууууя_19861 & -0.07669100 & -0.78 & -0.07665380 & -0.78 \\
\hline yyyyq_19862 & -0.06286220 & -0.66 & -0.06265060 & -0.66 \\
\hline yyyyq_19863 & -0.05191480 & -0.56 & -0.05174670 & -0.56 \\
\hline yyyyq_19864 & -0.02928690 & -0.32 & -0.02921820 & -0.32 \\
\hline yyyyq_19871 & -0.10424150 & -1.36 & -0.10441380 & -1.36 \\
\hline yyyyq_19872 & -0.09822290 & -1.29 & -0.09840280 & -1.29 \\
\hline yyyyq_19873 & -0.09941110 & -1.30 & -0.09958360 & -1.30 \\
\hline yyyyq_19874 & -0.11032860 & -1.45 & -0.11055000 & -1.45 \\
\hline yyyyq_19881 & -0.14758310 & -1.98 & -0.14778930 & -1.99 \\
\hline yyyyq_19882 & -0.15339120 & -2.07 & -0.15360660 & -2.07 \\
\hline yyyyq_19883 & -0.16924690 & -2.28 & -0.16946530 & -2.28 \\
\hline yyyyq_19884 & -0.21615170 & -2.91 & -0.21639850 & -2.91 \\
\hline yyyyq_19891 & -0.23314630 & -3.14 & -0.23338880 & -3.14 \\
\hline yyyyq_19892 & -0.24192040 & -3.25 & -0.24216700 & -3.25 \\
\hline yyyyq_19894 & -0.32476270 & -4.37 & -0.32498710 & -4.38 \\
\hline yyyyq_19901 & -0.33985180 & -4.59 & -0.34009540 & -4.60 \\
\hline yyyyq_19902 & -0.36513480 & -4.93 & -0.36537880 & -4.94 \\
\hline yуyуq_19903 & -0.37653540 & -5.09 & -0.37674520 & -5.10 \\
\hline уyуyq_19904 & -0.38840840 & -5.26 & -0.38866490 & -5.26 \\
\hline yyyyq_19911 & -0.38006220 & -5.15 & -0.38031870 & -5.15 \\
\hline yyyyq_19912 & -0.38211360 & -5.18 & -0.38234440 & -5.19 \\
\hline ууууд_19913 & -0.36916340 & -5.01 & -0.36938500 & -5.01 \\
\hline yyyyq_19914 & -0.32689450 & -4.43 & -0.32712330 & -4.44 \\
\hline yyyyq_19921 & -0.31761600 & -4.30 & -0.31787370 & -4.31 \\
\hline ууууд_19922 & -0.28782890 & -3.91 & -0.28805340 & -3.91 \\
\hline yyyyq_19923 & -0.00036270 & -0.02 & -0.00250760 & -0.14 \\
\hline yyyyq_19924 & -0.21314360 & -2.90 & -0.21338870 & -2.90 \\
\hline yyyyq_19931 & -0.20243990 & -2.75 & -0.20267600 & -2.76 \\
\hline yyyyq_19932 & -0.17757460 & -2.41 & -0.17781810 & -2.42 \\
\hline yyyyq_19933 & -0.16859040 & -2.29 & -0.16882150 & -2.30 \\
\hline yyyyq_19934 & -0.15931240 & -2.17 & -0.15954960 & -2.17 \\
\hline yyyyq_19941 & -0.15271660 & -2.08 & -0.15293420 & -2.08 \\
\hline ууууд_19942 & -0.14924980 & -2.03 & -0.14942790 & -2.03 \\
\hline yyyyq_19943 & -0.13319260 & -1.81 & -0.13335410 & -1.82 \\
\hline yуyуq_19944 & -0.12889990 & -1.75 & -0.12904220 & -1.76 \\
\hline yyyyq_19951 & -0.13109730 & -1.78 & -0.13124270 & -1.79 \\
\hline yyyyq_19952 & -0.12176330 & -1.66 & -0.12190880 & -1.66 \\
\hline yyyyq_19953 & -0.10507050 & -1.43 & -0.10521510 & -1.43 \\
\hline ууууд_19954 & -0.07552310 & -1.03 & -0.07570550 & -1.03 \\
\hline ууууд_19961 & -0.06993230 & -0.95 & -0.07014840 & -0.95 \\
\hline yyyyq_19962 & -0.05570120 & -0.76 & -0.05590950 & -0.76 \\
\hline ууууд_19963 & 0.19748380 & 11.60 & 0.19621510 & 11.52 \\
\hline
\end{tabular}

Dummy vari- $\quad$ Coefficient (1) $t$-stat (1) Coefficient (2) $t$-stat (2) able

\begin{tabular}{|c|c|c|c|c|}
\hline 19964 & -0.05524410 & -0.75 & -0.05545580 & -0.75 \\
\hline ууууд_19971 & -0.05735300 & -0.78 & -0.05754380 & -0.78 \\
\hline ууууд_19972 & -0.06629550 & -0.90 & -0.06648180 & -0.91 \\
\hline yyyyq_19973 & -0.07319480 & -1.00 & -0.07338530 & -1.00 \\
\hline yуyуq_19974 & -0.09193420 & -1.25 & -0.09210540 & -1.26 \\
\hline ууууд_19981 & -0.09811930 & -1.34 & -0.09827660 & -1.34 \\
\hline ууууд_19982 & -0.10344660 & -1.41 & -0.10361530 & -1.41 \\
\hline уyyyq_19983 & -0.10550190 & -1.44 & -0.10566160 & -1.44 \\
\hline ууууя_19984 & -0.11681660 & -1.59 & -0.11696840 & -1.60 \\
\hline ууууд_19991 & -0.12166000 & -1.66 & -0.12183820 & -1.66 \\
\hline yyyyq_19992 & -0.12534610 & -1.71 & -0.12551910 & -1.71 \\
\hline ууууд_19993 & 0.11601060 & 7.20 & 0.11622430 & 7.22 \\
\hline ууууд_19994 & -0.16960610 & -2.31 & -0.16978330 & -2.32 \\
\hline ууууя_20001 & -0.17470770 & -2.38 & -0.17487810 & -2.39 \\
\hline ууууд_20002 & -0.19271280 & -2.63 & -0.19286580 & -2.63 \\
\hline yуyуq_20003 & -0.20101940 & -2.74 & -0.20116310 & -2.75 \\
\hline ууууя_20004 & -0.22048120 & -3.01 & -0.22063380 & -3.01 \\
\hline yyyyq_20011 & -0.23665740 & -3.23 & -0.23681730 & -3.23 \\
\hline ууууд_20012 & 0.02847760 & 1.81 & 0.02858290 & 1.81 \\
\hline ууyуq_20013 & -0.24567900 & -3.36 & -0.24583230 & -3.36 \\
\hline ууууя_20014 & -0.24292020 & -3.32 & -0.24308070 & -3.32 \\
\hline ууууд_20021 & -0.22537760 & -3.08 & -0.22556240 & -3.08 \\
\hline yyyyq_20022 & -0.20951310 & -2.86 & -0.20973680 & -2.87 \\
\hline ууууя_20023 & -0.18865390 & -2.58 & -0.18887910 & -2.58 \\
\hline ууууд_20024 & -0.19805760 & -2.71 & -0.19830570 & -2.71 \\
\hline yyyyq_20031 & -0.13908620 & -1.90 & -0.13933310 & -1.90 \\
\hline yуyуq_20032 & -0.18820120 & -2.57 & -0.18844380 & -2.58 \\
\hline уyуyq_20033 & 0.13966830 & 8.94 & 0.13677690 & 8.76 \\
\hline ууууд_20034 & -0.09703900 & -1.33 & -0.09726360 & -1.33 \\
\hline yуyyq_20041 & -0.04389540 & -0.60 & -0.04412190 & -0.60 \\
\hline ууууд_20042 & -0.02613820 & -0.36 & -0.02634300 & -0.36 \\
\hline yyyyq_20043 & 0.24147530 & 16.18 & 0.23826680 & 15.96 \\
\hline ууууд_20044 & -0.02147050 & -0.29 & -0.02163840 & -0.30 \\
\hline уyуyq_20051 & -0.00318710 & -0.04 & -0.00335910 & -0.05 \\
\hline ууууя_20052 & 0.00280650 & 0.04 & 0.00269800 & 0.04 \\
\hline yyyyq_20053 & 0.24307570 & 16.21 & 0.23842970 & 15.90 \\
\hline ууyуд_20054 & 0.22614080 & 14.69 & 0.22146830 & 14.38 \\
\hline ууууд_20061 & -0.04951130 & -0.68 & -0.04963050 & -0.68 \\
\hline yyyyq_20062 & -0.08639170 & -1.18 & -0.08649160 & -1.18 \\
\hline ууууд_20063 & -0.12472230 & -1.71 & -0.12482910 & -1.71 \\
\hline ууууя_20064 & -0.24055330 & -3.29 & -0.24066160 & -3.29 \\
\hline ууууя_20071 & -0.33102210 & -4.53 & -0.33114730 & -4.53 \\
\hline yyyyq_20072 & -0.41346090 & -5.66 & -0.41359250 & -5.66 \\
\hline ууууд_20073 & -0.47112360 & -6.44 & -0.47126680 & -6.45 \\
\hline ууууд_20074 & -0.50349110 & -6.89 & -0.50364190 & -6.89 \\
\hline yyyyq_20081 & -0.50934650 & -6.97 & -0.50950560 & -6.97 \\
\hline ууууд_20082 & -0.50359730 & -6.89 & -0.50376680 & -6.89 \\
\hline ууууя_20083 & -0.22405520 & -15.09 & -0.22685090 & -15.28 \\
\hline ууууд_20084 & -0.40210170 & -5.50 & -0.40231170 & -5.51 \\
\hline yyyyq_20091 & -0.32388370 & -4.43 & -0.32411030 & -4.43 \\
\hline
\end{tabular}


\begin{tabular}{lllll}
\hline Dummy vari- & Coefficient (1) & $t$-stat (1) Coefficient (2) & $t$-stat (2)
\end{tabular} able

\begin{tabular}{|c|c|c|c|c|}
\hline 092 & 0 & 3.05 & 26680 & 3.05 \\
\hline 0093 & 0 & 2.34 & 30 & \\
\hline yyyq_20094 & -0.11369210 & 1.56 & 6770 & 6 \\
\hline уууд_20101 & -0 & 41 & 50 & 42 \\
\hline q_20102 & 0 & 06 & 50 & .07 \\
\hline _20103 & 30 & 48 & 40 & 48 \\
\hline 04 & $-c$ & -1.76 & -0 & -1.76 \\
\hline & -0 & -1.87 & -0 & \\
\hline & 10 & 91 & -0 & \\
\hline & 80 & 8.50 & & 8.41 \\
\hline 114 & -0.15065190 & 2.06 & -0.1 & -2.07 \\
\hline yyyq_20121 & -0.1348 & -1.84 & -0.1 & -1.85 \\
\hline I_20122 & -0.1 & -1.77 & -0.12 & -1.77 \\
\hline 123 & -0.1 & -1.89 & 90 & -1.90 \\
\hline 24 & 20 & 8.03 & 50 & 7.88 \\
\hline l_20131 & -0 & -1.39 & -0.1 & -1.40 \\
\hline 132 & -0.09 & -1.32 & -0 & -1.33 \\
\hline 133 & -0.0 & -1.36 & -0 & -1.36 \\
\hline 134 & -0 & -1.52 & -0 & - \\
\hline 141 & -0 & - & -( & - \\
\hline yyyq_2 & -0 & - & & 32 \\
\hline jyyyq_2 & -0 & & & \\
\hline yyyq_2 & & & & \\
\hline 51 & & & & \\
\hline 'уууд_2 & -0.12 & -1.74 & -0.1 & -1.74 \\
\hline q_20153 & -0.14955400 & -2.05 & -0.1 & -2.05 \\
\hline 154 & -0.15 & -2.18 & -0.1 & -2.17 \\
\hline 161 & -0 & -2.00 & $-c$ & -2.00 \\
\hline I_20162 & -0 & -1.95 & -0 & -1.95 \\
\hline 63 & -0.1 & -1.98 & -0 & -1.98 \\
\hline 164 & 0.10 & 7.12 & 00 & 6.77 \\
\hline yyyq_20171 & -0.1 & -1.95 & -0 & -1.95 \\
\hline yyyq_20172 & -0.1 & -1.95 & -0 & -1.95 \\
\hline q_20173 & 0 & 7.26 & & 6.92 \\
\hline $\begin{array}{l}\text { CBSAor- } \\
\text { Div_10500 }\end{array}$ & 70 & 1.80 & 60 & 1.82 \\
\hline $\begin{array}{l}\text { CBSAor- } \\
\text { Div_10580 }\end{array}$ & .08396940 & 13 & 0.08340060 & -2.12 \\
\hline $\begin{array}{l}\text { CBSAor- } \\
\text { Div_10740 }\end{array}$ & .02741100 & 1.09 & 0.02579920 & -1.03 \\
\hline $\begin{array}{l}\text { CBSAor- } \\
\text { Div_10900 }\end{array}$ & 30 & .31 & 80 & 2.25 \\
\hline $\begin{array}{l}\text { CBSAor } \\
\text { Div_1 }\end{array}$ & .09550510 & .33 & 0.09376300 & -1.31 \\
\hline $\begin{array}{l}\text { CBSA } \\
\text { Div }\end{array}$ & .11377710 & 2.56 & -0.11245190 & -2.53 \\
\hline $\begin{array}{r}\text { CBS } \\
\text { Div }\end{array}$ & -0.01318390 & 0.07 & -0.01252100 & -0.06 \\
\hline $\begin{array}{r}\text { CBS } \\
\text { Di }\end{array}$ & 90 & 2.60 & 30 & 2.01 \\
\hline $\begin{array}{l}\text { CBSAor- } \\
\text { Div_11260 }\end{array}$ & -0.00872410 & -0.31 & -0.00736510 & -0.26 \\
\hline
\end{tabular}

\begin{tabular}{lllll}
\hline Dummy vari- & Coefficient (1) & $t$-stat (1) Coefficient (2) & $t$-stat (2)
\end{tabular} able

\begin{tabular}{|c|c|c|c|c|}
\hline $\begin{array}{l}\text { CBSAor- } \\
\text { Div_11460 }\end{array}$ & 0.03630710 & 1.38 & 0.03803020 & 1.45 \\
\hline $\begin{array}{l}\text { CBSAor- } \\
\text { Div_11700 }\end{array}$ & 0.12314920 & 2.33 & 0.12465180 & 2.36 \\
\hline $\begin{array}{l}\text { CBSAor- } \\
\text { Div_11820 }\end{array}$ & 0.06432920 & 0.59 & 0.06539830 & 0.60 \\
\hline $\begin{array}{l}\text { CBSAor- } \\
\text { Div_12020 }\end{array}$ & -0.00727200 & -0.14 & -0.00642160 & -0.12 \\
\hline $\begin{array}{l}\text { CBSAor- } \\
\text { Div_12060 }\end{array}$ & 0.01238940 & 0.59 & 0.01199300 & 0.57 \\
\hline $\begin{array}{l}\text { CBSAor- } \\
\text { Div_12140 }\end{array}$ & -0.02782970 & -0.45 & -0.03054300 & -0.49 \\
\hline $\begin{array}{l}\text { CBSAor- } \\
\text { Div_12220 }\end{array}$ & 0.00310030 & 0.04 & 0.00591370 & 0.08 \\
\hline $\begin{array}{l}\text { CBSAor- } \\
\text { Div_12260 }\end{array}$ & -0.03616970 & -0.94 & -0.03433420 & -0.89 \\
\hline $\begin{array}{l}\text { CBSAor- } \\
\text { Div_12300 }\end{array}$ & 0.05425160 & 0.80 & 0.05724100 & 0.84 \\
\hline $\begin{array}{l}\text { CBSAor- } \\
\text { Div_12420 }\end{array}$ & 0.04505750 & 2.12 & 0.04617740 & 2.17 \\
\hline $\begin{array}{l}\text { CBSAor- } \\
\text { Div_12540 }\end{array}$ & 0.02056440 & 0.65 & 0.02275120 & 0.72 \\
\hline $\begin{array}{l}\text { CBSAor- } \\
\text { Div_12580 }\end{array}$ & 0.02782890 & 1.30 & 0.02776190 & 1.30 \\
\hline $\begin{array}{l}\text { CBSAor- } \\
\text { Div_12620 }\end{array}$ & -0.03350870 & -0.33 & -0.03305450 & -0.32 \\
\hline $\begin{array}{l}\text { CBSAor- } \\
\text { Div_12700 }\end{array}$ & -0.01949730 & -0.52 & -0.01708590 & -0.45 \\
\hline $\begin{array}{l}\text { CBSAor- } \\
\text { Div_12860 }\end{array}$ & 0.13639550 & 2.18 & 0.13366010 & 2.14 \\
\hline $\begin{array}{l}\text { CBSAor- } \\
\text { Div_12940 }\end{array}$ & -0.01246580 & -0.44 & -0.01065380 & -0.38 \\
\hline $\begin{array}{l}\text { CBSAor- } \\
\text { Div_13140 }\end{array}$ & -0.38808790 & -4.02 & -0.38700080 & -4.01 \\
\hline $\begin{array}{l}\text { CBSAor- } \\
\text { Div_13300 }\end{array}$ & 0.11265990 & 1.77 & 0.11392330 & 1.79 \\
\hline $\begin{array}{l}\text { CBSAor- } \\
\text { Div_13380 }\end{array}$ & -0.20068680 & -1.22 & -0.19881110 & -1.21 \\
\hline $\begin{array}{l}\text { CBSAor- } \\
\text { Div_13780 }\end{array}$ & -0.40636040 & -4.82 & -0.40553000 & -4.81 \\
\hline $\begin{array}{l}\text { CBSAor- } \\
\text { Div_13820 }\end{array}$ & -0.01877840 & -0.74 & -0.01665950 & -0.66 \\
\hline $\begin{array}{l}\text { CBSAor- } \\
\text { Div_13980 }\end{array}$ & 0.05279690 & 0.88 & 0.05385080 & 0.89 \\
\hline $\begin{array}{l}\text { CBSAor- } \\
\text { Div_14010 }\end{array}$ & -0.00011130 & 0.00 & 0.00068930 & 0.02 \\
\hline $\begin{array}{l}\text { CBSAor- } \\
\text { Div_14020 }\end{array}$ & -0.07013260 & -0.92 & -0.06860190 & -0.90 \\
\hline $\begin{array}{l}\text { CBSAor- } \\
\text { Div_14100 }\end{array}$ & 0.03582320 & 0.54 & 0.03773570 & 0.57 \\
\hline $\begin{array}{l}\text { CBSAor- } \\
\text { Div_14260 }\end{array}$ & 0.00875670 & 0.15 & 0.01053660 & 0.19 \\
\hline $\begin{array}{l}\text { CBSAor- } \\
\text { Div_14454 }\end{array}$ & 0.03990870 & 1.86 & 0.04158780 & 1.94 \\
\hline
\end{tabular}




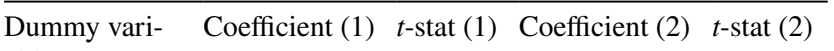
able

\begin{tabular}{|c|c|c|c|c|}
\hline $\begin{array}{l}\text { CBSAor- } \\
\text { Div_14500 }\end{array}$ & 0.01384760 & 0.62 & 0.01343010 & 0.60 \\
\hline $\begin{array}{l}\text { CBSAor- } \\
\text { Div_14540 }\end{array}$ & 0.29152510 & 1.77 & 0.27989230 & 1.70 \\
\hline $\begin{array}{l}\text { CBSAor- } \\
\text { Div_14860 }\end{array}$ & 0.01029260 & 0.45 & 0.01309990 & 0.57 \\
\hline $\begin{array}{l}\text { CBSAor- } \\
\text { Div_15180 }\end{array}$ & -0.08061200 & -1.43 & -0.08074740 & -1.43 \\
\hline $\begin{array}{l}\text { CBSAor- } \\
\text { Div_15260 }\end{array}$ & -0.13339490 & -1.45 & -0.13295800 & -1.45 \\
\hline $\begin{array}{l}\text { CBSAor- } \\
\text { Div_15380 }\end{array}$ & -0.13551330 & -3.28 & -0.13490930 & -3.26 \\
\hline $\begin{array}{l}\text { CBSAor- } \\
\text { Div_15460 }\end{array}$ & -0.21293390 & -2.32 & -0.21188710 & -2.31 \\
\hline $\begin{array}{l}\text { CBSAor- } \\
\text { Div_15660 }\end{array}$ & 0.03020140 & 0.48 & 0.03120030 & 0.50 \\
\hline $\begin{array}{l}\text { CBSAor- } \\
\text { Div_15680 }\end{array}$ & -0.06368730 & -1.14 & -0.06798280 & -1.22 \\
\hline $\begin{array}{l}\text { CBSAor- } \\
\text { Div_15764 }\end{array}$ & 0.01487390 & 0.70 & 0.01653080 & 0.77 \\
\hline $\begin{array}{l}\text { CBSAor- } \\
\text { Div_15804 }\end{array}$ & 0.02686060 & 1.22 & 0.02632430 & 1.19 \\
\hline $\begin{array}{l}\text { CBSAor- } \\
\text { Div_15820 }\end{array}$ & -0.11706110 & -1.44 & -0.12072400 & -1.49 \\
\hline $\begin{array}{l}\text { CBSAor- } \\
\text { Div_15940 }\end{array}$ & -0.08229190 & -0.90 & -0.08127590 & -0.89 \\
\hline $\begin{array}{l}\text { CBSAor- } \\
\text { Div_15980 }\end{array}$ & 0.04378260 & 1.83 & 0.04517490 & 1.89 \\
\hline $\begin{array}{l}\text { CBSAor- } \\
\text { Div_16060 }\end{array}$ & -0.50701390 & -4.66 & -0.50643830 & -4.65 \\
\hline $\begin{array}{l}\text { CBSAor- } \\
\text { Div_16180 }\end{array}$ & -0.15942930 & -2.03 & -0.15785000 & -2.01 \\
\hline $\begin{array}{l}\text { CBSAor- } \\
\text { Div_16300 }\end{array}$ & -0.08494010 & -0.97 & -0.08435320 & -0.96 \\
\hline $\begin{array}{l}\text { CBSAor- } \\
\text { Div_16540 }\end{array}$ & 0.04296480 & 0.84 & 0.04053850 & 0.80 \\
\hline $\begin{array}{l}\text { CBSAor- } \\
\text { Div_16580 }\end{array}$ & -0.04801020 & -0.72 & -0.04734270 & -0.71 \\
\hline $\begin{array}{l}\text { CBSAor- } \\
\text { Div_16700 }\end{array}$ & 0.06947770 & 2.52 & 0.07144950 & 2.59 \\
\hline $\begin{array}{l}\text { CBSAor- } \\
\text { Div_16740 }\end{array}$ & 0.01860070 & 0.86 & 0.01963120 & 0.91 \\
\hline $\begin{array}{l}\text { CBSAor- } \\
\text { Div_16820 }\end{array}$ & -0.01645690 & -0.46 & -0.01317210 & -0.37 \\
\hline $\begin{array}{l}\text { CBSAor- } \\
\text { Div_16860 }\end{array}$ & 0.09295770 & 1.64 & 0.09378300 & 1.66 \\
\hline $\begin{array}{l}\text { CBSAor- } \\
\text { Div_16974 }\end{array}$ & 0.01041280 & 0.49 & 0.01039410 & 0.49 \\
\hline $\begin{array}{l}\text { CBSAor- } \\
\text { Div_17020 }\end{array}$ & -0.17558810 & -2.38 & -0.17617770 & -2.39 \\
\hline $\begin{array}{l}\text { CBSAor- } \\
\text { Div_17140 }\end{array}$ & -0.02496500 & -1.14 & -0.02533920 & -1.16 \\
\hline $\begin{array}{l}\text { CBSAor- } \\
\text { Div_17200 }\end{array}$ & -0.11153780 & -0.56 & -0.11087520 & -0.55 \\
\hline
\end{tabular}

\begin{tabular}{lllll}
\hline Dummy vari- & Coefficient (1) & $t$-stat (1) Coefficient (2) & $t$-stat (2)
\end{tabular} able

\begin{tabular}{|c|c|c|c|c|}
\hline $\begin{array}{l}\text { CBSAor- } \\
\text { Div_17460 }\end{array}$ & -0.05582420 & -2.30 & -0.05413760 & -2.23 \\
\hline $\begin{array}{l}\text { CBSAor- } \\
\text { Div_17660 }\end{array}$ & 0.06682720 & 1.15 & 0.06857920 & 1.18 \\
\hline $\begin{array}{l}\text { CBSAor- } \\
\text { Div_17780 }\end{array}$ & -0.04524050 & -0.99 & -0.04245070 & -0.93 \\
\hline $\begin{array}{l}\text { CBSAor- } \\
\text { Div_17820 }\end{array}$ & 0.01952470 & 0.80 & 0.02175420 & 0.90 \\
\hline $\begin{array}{l}\text { CBSAor- } \\
\text { Div_17860 }\end{array}$ & -0.01106770 & -0.22 & -0.00843200 & -0.17 \\
\hline $\begin{array}{l}\text { CBSAor- } \\
\text { Div_17900 }\end{array}$ & 0.02982490 & 1.15 & 0.03077250 & 1.19 \\
\hline $\begin{array}{l}\text { CBSAor- } \\
\text { Div_17980 }\end{array}$ & -0.14734160 & -1.94 & -0.14332160 & -1.89 \\
\hline $\begin{array}{l}\text { CBSAor- } \\
\text { Div_18140 }\end{array}$ & -0.03751700 & -1.71 & -0.03623940 & -1.65 \\
\hline $\begin{array}{l}\text { CBSAor- } \\
\text { Div_18180 }\end{array}$ & -0.12806460 & -2.40 & -0.12453000 & -2.33 \\
\hline $\begin{array}{l}\text { CBSAor- } \\
\text { Div_18420 }\end{array}$ & -0.10770200 & -0.54 & -0.10701360 & -0.53 \\
\hline $\begin{array}{l}\text { CBSAor- } \\
\text { Div_18580 }\end{array}$ & 0.06517690 & 2.21 & 0.06647750 & 2.26 \\
\hline $\begin{array}{l}\text { CBSAor- } \\
\text { Div_18880 }\end{array}$ & -0.08362120 & -1.48 & -0.08269440 & -1.46 \\
\hline $\begin{array}{l}\text { CBSAor- } \\
\text { Div_18900 }\end{array}$ & 0.00838220 & 0.13 & 0.00929930 & 0.15 \\
\hline $\begin{array}{l}\text { CBSAor- } \\
\text { Div_19124 }\end{array}$ & 0.01901320 & 0.90 & 0.01899260 & 0.90 \\
\hline $\begin{array}{l}\text { CBSAor- } \\
\text { Div_19140 }\end{array}$ & -0.10346700 & -1.62 & -0.10246010 & -1.61 \\
\hline $\begin{array}{l}\text { CBSAor- } \\
\text { Div_19220 }\end{array}$ & 0.00291180 & 0.04 & 0.00369330 & 0.06 \\
\hline $\begin{array}{l}\text { CBSAor- } \\
\text { Div_19340 }\end{array}$ & -0.07833080 & -1.92 & -0.07756310 & -1.90 \\
\hline $\begin{array}{l}\text { CBSAor- } \\
\text { Div_19380 }\end{array}$ & -0.01826220 & -0.52 & -0.01701250 & -0.48 \\
\hline $\begin{array}{l}\text { CBSAor- } \\
\text { Div_19500 }\end{array}$ & 0.01064810 & 0.26 & 0.00908340 & 0.22 \\
\hline $\begin{array}{l}\text { CBSAor- } \\
\text { Div_19660 }\end{array}$ & 0.04641600 & 1.39 & 0.04804730 & 1.44 \\
\hline $\begin{array}{l}\text { CBSAor- } \\
\text { Div_19740 }\end{array}$ & 0.04525330 & 2.13 & 0.04674530 & 2.20 \\
\hline $\begin{array}{l}\text { CBSAor- } \\
\text { Div_19780 }\end{array}$ & -0.07783360 & -2.35 & -0.07648890 & -2.31 \\
\hline $\begin{array}{l}\text { CBSAor- } \\
\text { Div_19804 }\end{array}$ & 0.03239320 & 1.41 & 0.03166430 & 1.38 \\
\hline $\begin{array}{l}\text { CBSAor- } \\
\text { Div_20260 }\end{array}$ & 0.05819300 & 0.63 & 0.05849880 & 0.64 \\
\hline $\begin{array}{l}\text { CBSAor- } \\
\text { Div_20500 }\end{array}$ & 0.03996940 & 1.74 & 0.04107220 & 1.79 \\
\hline $\begin{array}{l}\text { CBSAor- } \\
\text { Div_20524 }\end{array}$ & -0.03546880 & -0.79 & -0.02996150 & -0.66 \\
\hline $\begin{array}{l}\text { CBSAor- } \\
\text { Div_20780 }\end{array}$ & 0.00498100 & 0.11 & 0.01545490 & 0.35 \\
\hline
\end{tabular}


Dummy vari- $\quad$ Coefficient (1) $t$-stat (1) Coefficient (2) $t$-stat (2) able

\begin{tabular}{|c|c|c|c|c|}
\hline $\begin{array}{l}\text { CBSAor- } \\
\text { Div_20900 }\end{array}$ & -0.01872830 & -0.29 & -0.01771620 & -0.28 \\
\hline $\begin{array}{l}\text { CBSAor- } \\
\text { Div_20994 }\end{array}$ & -0.01737660 & -0.74 & -0.01839430 & -0.78 \\
\hline $\begin{array}{l}\text { CBSAor- } \\
\text { Div_21340 }\end{array}$ & -0.01421310 & -0.47 & -0.01473380 & -0.49 \\
\hline $\begin{array}{l}\text { CBSAor- } \\
\text { Div_21420 }\end{array}$ & -0.31240480 & -5.84 & -0.31258560 & -5.85 \\
\hline $\begin{array}{l}\text { CBSAor- } \\
\text { Div_21460 }\end{array}$ & 0.25771070 & 1.28 & 0.25717690 & 1.28 \\
\hline $\begin{array}{l}\text { CBSAor- } \\
\text { Div_21660 }\end{array}$ & 0.02442750 & 0.60 & 0.02520400 & 0.62 \\
\hline $\begin{array}{l}\text { CBSAor- } \\
\text { Div_21780 }\end{array}$ & -0.08935260 & -1.46 & -0.08893760 & -1.45 \\
\hline $\begin{array}{l}\text { CBSAor- } \\
\text { Div_22020 }\end{array}$ & 0.05149970 & 0.82 & 0.04866950 & 0.78 \\
\hline $\begin{array}{l}\text { CBSAor- } \\
\text { Div_22140 }\end{array}$ & -0.21965260 & -3.30 & -0.22092540 & -3.32 \\
\hline $\begin{array}{l}\text { CBSAor- } \\
\text { Div_22180 }\end{array}$ & -0.09044250 & -2.86 & -0.08956520 & -2.83 \\
\hline $\begin{array}{l}\text { CBSAor- } \\
\text { Div_22220 }\end{array}$ & -0.04999760 & -0.95 & -0.04962940 & -0.94 \\
\hline $\begin{array}{l}\text { CBSAor- } \\
\text { Div_22280 }\end{array}$ & -0.11396160 & -2.33 & -0.11872020 & -2.43 \\
\hline $\begin{array}{l}\text { CBSAor- } \\
\text { Div_22380 }\end{array}$ & 0.00375700 & 0.03 & 0.00456880 & 0.04 \\
\hline $\begin{array}{l}\text { CBSAor- } \\
\text { Div_22420 }\end{array}$ & -0.04576900 & -1.12 & -0.04521160 & -1.11 \\
\hline $\begin{array}{l}\text { CBSAor- } \\
\text { Div_22500 }\end{array}$ & -0.07547880 & -1.16 & -0.07586360 & -1.16 \\
\hline $\begin{array}{l}\text { CBSAor- } \\
\text { Div_22520 }\end{array}$ & -0.12347620 & -1.86 & -0.12200010 & -1.83 \\
\hline $\begin{array}{l}\text { CBSAor- } \\
\text { Div_22660 }\end{array}$ & -1.07313000 & -7.52 & -1.07234300 & -7.51 \\
\hline $\begin{array}{l}\text { CBSAor- } \\
\text { Div_22744 }\end{array}$ & 0.04309670 & 2.02 & 0.04382580 & 2.06 \\
\hline $\begin{array}{l}\text { CBSAor- } \\
\text { Div_22800 }\end{array}$ & -0.14298820 & -0.71 & -0.14269820 & -0.71 \\
\hline $\begin{array}{l}\text { CBSAor- } \\
\text { Div_22900 }\end{array}$ & -0.04834980 & -0.69 & -0.04673860 & -0.67 \\
\hline $\begin{array}{l}\text { CBSAor- } \\
\text { Div_23060 }\end{array}$ & -0.09769120 & -2.48 & -0.09800110 & -2.49 \\
\hline $\begin{array}{l}\text { CBSAor- } \\
\text { Div_23104 }\end{array}$ & 0.02338470 & 1.08 & 0.02292470 & 1.06 \\
\hline $\begin{array}{l}\text { CBSAor- } \\
\text { Div_23420 }\end{array}$ & 0.04362630 & 1.20 & 0.04701840 & 1.30 \\
\hline $\begin{array}{l}\text { CBSAor- } \\
\text { Div_23540 }\end{array}$ & 0.06284370 & 1.76 & 0.06519350 & 1.82 \\
\hline $\begin{array}{l}\text { CBSAor- } \\
\text { Div_23580 }\end{array}$ & -0.01498980 & -0.25 & -0.01331430 & -0.22 \\
\hline $\begin{array}{l}\text { CBSAor- } \\
\text { Div_23844 }\end{array}$ & 0.05163210 & 1.98 & 0.04933540 & 1.89 \\
\hline $\begin{array}{l}\text { CBSAor- } \\
\text { Div_24020 }\end{array}$ & -0.12629830 & -0.45 & -0.12541080 & -0.44 \\
\hline
\end{tabular}

Dummy vari- Coefficient (1) $t$-stat (1) Coefficient (2) $t$-stat (2) able

\begin{tabular}{|c|c|c|c|c|}
\hline $\begin{array}{l}\text { CBSAor- } \\
\text { Div_24220 }\end{array}$ & 0.10069130 & 1.04 & 0.10149390 & 1.05 \\
\hline $\begin{array}{l}\text { CBSAor- } \\
\text { Div_24300 }\end{array}$ & 0.03257670 & 0.42 & 0.03341970 & 0.43 \\
\hline $\begin{array}{l}\text { CBSAor- } \\
\text { Div_24340 }\end{array}$ & 0.00993710 & 0.25 & 0.01191070 & 0.31 \\
\hline $\begin{array}{l}\text { CBSAor- } \\
\text { Div_24540 }\end{array}$ & 0.01709620 & 0.27 & 0.01849030 & 0.29 \\
\hline $\begin{array}{l}\text { CBSAor- } \\
\text { Div_24660 }\end{array}$ & 0.01053820 & 0.42 & 0.01212440 & 0.48 \\
\hline $\begin{array}{l}\text { CBSAor- } \\
\text { Div_24780 }\end{array}$ & 0.06961350 & 0.89 & 0.07231600 & 0.92 \\
\hline $\begin{array}{l}\text { CBSAor- } \\
\text { Div_24860 }\end{array}$ & 0.02930090 & 1.15 & 0.03144370 & 1.23 \\
\hline $\begin{array}{l}\text { CBSAor- } \\
\text { Div_25060 }\end{array}$ & 0.00469960 & 0.07 & 0.00615690 & 0.09 \\
\hline $\begin{array}{l}\text { CBSAor- } \\
\text { Div_25180 }\end{array}$ & 0.02341100 & 0.37 & 0.02504250 & 0.39 \\
\hline $\begin{array}{l}\text { CBSAor- } \\
\text { Div_25420 }\end{array}$ & -0.00325570 & -0.14 & -0.00425250 & -0.18 \\
\hline $\begin{array}{l}\text { CBSAor- } \\
\text { Div_25500 }\end{array}$ & 0.00800100 & 0.10 & 0.00910590 & 0.12 \\
\hline $\begin{array}{l}\text { CBSAor- } \\
\text { Div_25540 }\end{array}$ & -0.02058250 & -0.87 & -0.01891210 & -0.80 \\
\hline $\begin{array}{l}\text { CBSAor- } \\
\text { Div_25620 }\end{array}$ & -0.06269930 & -0.74 & -0.06172510 & -0.73 \\
\hline $\begin{array}{l}\text { CBSAor- } \\
\text { Div_25860 }\end{array}$ & 0.18015570 & 2.88 & 0.18098160 & 2.89 \\
\hline $\begin{array}{l}\text { CBSAor- } \\
\text { Div_25900 }\end{array}$ & 0.04843830 & 1.02 & 0.04993700 & 1.05 \\
\hline $\begin{array}{l}\text { CBSAor- } \\
\text { Div_25940 }\end{array}$ & 0.04400040 & 0.93 & 0.04560000 & 0.96 \\
\hline $\begin{array}{l}\text { CBSAor- } \\
\text { Div_26300 }\end{array}$ & -0.19753070 & -2.68 & -0.19662010 & -2.67 \\
\hline $\begin{array}{l}\text { CBSAor- } \\
\text { Div_26380 }\end{array}$ & -0.09820290 & -1.12 & -0.09708420 & -1.11 \\
\hline $\begin{array}{l}\text { CBSAor- } \\
\text { Div_26420 }\end{array}$ & 0.04277830 & 2.02 & 0.04327510 & 2.04 \\
\hline $\begin{array}{l}\text { CBSAor- } \\
\text { Div_26580 }\end{array}$ & -0.21304570 & -2.09 & -0.21279880 & -2.09 \\
\hline $\begin{array}{l}\text { CBSAor- } \\
\text { Div_26620 }\end{array}$ & -0.06389590 & -1.90 & -0.06235820 & -1.85 \\
\hline $\begin{array}{l}\text { CBSAor- } \\
\text { Div_26660 }\end{array}$ & 0.03734950 & 0.44 & 0.04074800 & 0.48 \\
\hline $\begin{array}{l}\text { CBSAor- } \\
\text { Div_26900 }\end{array}$ & -0.00501170 & -0.23 & -0.00716010 & -0.33 \\
\hline $\begin{array}{l}\text { CBSAor- } \\
\text { Div_26980 }\end{array}$ & -0.01299940 & -0.29 & -0.01180170 & -0.27 \\
\hline $\begin{array}{l}\text { CBSAor- } \\
\text { Div_27140 }\end{array}$ & 0.00105320 & 0.03 & -0.00103830 & -0.03 \\
\hline $\begin{array}{l}\text { CBSAor- } \\
\text { Div_27180 }\end{array}$ & -0.03885350 & -0.68 & -0.03732500 & -0.65 \\
\hline $\begin{array}{l}\text { CBSAor- } \\
\text { Div_27260 }\end{array}$ & -0.00500550 & -0.22 & -0.00376920 & -0.17 \\
\hline
\end{tabular}




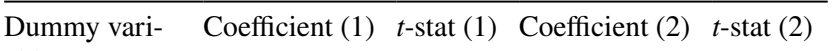
able

\begin{tabular}{|c|c|c|c|c|}
\hline $\begin{array}{l}\text { CBSAor- } \\
\text { Div_27340 }\end{array}$ & -0.12389810 & -1.90 & -0.12207590 & -1.88 \\
\hline $\begin{array}{l}\text { CBSAor- } \\
\text { Div_27540 }\end{array}$ & -0.03316060 & -0.49 & -0.03322090 & -0.49 \\
\hline $\begin{array}{l}\text { CBSAor- } \\
\text { Div_27600 }\end{array}$ & -0.02188440 & -0.64 & -0.02590390 & -0.76 \\
\hline $\begin{array}{l}\text { CBSAor- } \\
\text { Div_27620 }\end{array}$ & 0.03047900 & 0.77 & 0.03205990 & 0.81 \\
\hline $\begin{array}{l}\text { CBSAor- } \\
\text { Div_27740 }\end{array}$ & -0.18996690 & -1.86 & -0.18481280 & -1.81 \\
\hline $\begin{array}{l}\text { CBSAor- } \\
\text { Div_27940 }\end{array}$ & 0.01473010 & 0.37 & 0.01913670 & 0.48 \\
\hline $\begin{array}{l}\text { CBSAor- } \\
\text { Div_27980 }\end{array}$ & 0.01742060 & 0.54 & 0.01920880 & 0.59 \\
\hline $\begin{array}{l}\text { CBSAor- } \\
\text { Div_28020 }\end{array}$ & 0.03386090 & 0.89 & 0.03585760 & 0.95 \\
\hline $\begin{array}{l}\text { CBSAor- } \\
\text { Div_28140 }\end{array}$ & 0.00638570 & 0.29 & 0.00617970 & 0.28 \\
\hline $\begin{array}{l}\text { CBSAor- } \\
\text { Div_28180 }\end{array}$ & 0.04314310 & 1.35 & 0.04701960 & 1.47 \\
\hline $\begin{array}{l}\text { CBSAor- } \\
\text { Div_28420 }\end{array}$ & 0.07350300 & 1.76 & 0.07546730 & 1.80 \\
\hline $\begin{array}{l}\text { CBSAor- } \\
\text { Div_28540 }\end{array}$ & -0.22172320 & -3.74 & -0.21992460 & -3.71 \\
\hline $\begin{array}{l}\text { CBSAor- } \\
\text { Div_28580 }\end{array}$ & -0.07205850 & -0.86 & -0.07077190 & -0.84 \\
\hline $\begin{array}{l}\text { CBSAor- } \\
\text { Div_28660 }\end{array}$ & -0.00999690 & -0.25 & -0.00848790 & -0.21 \\
\hline $\begin{array}{l}\text { CBSAor- } \\
\text { Div_28700 }\end{array}$ & 0.04783380 & 0.76 & 0.04884910 & 0.78 \\
\hline $\begin{array}{l}\text { CBSAor- } \\
\text { Div_28740 }\end{array}$ & -0.05271780 & -0.57 & -0.05129700 & -0.56 \\
\hline $\begin{array}{l}\text { CBSAor- } \\
\text { Div_28940 }\end{array}$ & 0.02708640 & 1.10 & 0.02908350 & 1.18 \\
\hline $\begin{array}{l}\text { CBSAor- } \\
\text { Div_29100 }\end{array}$ & 0.10401280 & 2.23 & 0.10502040 & 2.25 \\
\hline $\begin{array}{l}\text { CBSAor- } \\
\text { Div_29180 }\end{array}$ & 0.01868120 & 0.35 & 0.01690060 & 0.32 \\
\hline $\begin{array}{l}\text { CBSAor- } \\
\text { Div_29200 }\end{array}$ & 0.02833120 & 0.81 & 0.02940900 & 0.84 \\
\hline $\begin{array}{l}\text { CBSAor- } \\
\text { Div_29404 }\end{array}$ & 0.00109660 & 0.05 & 0.00130480 & 0.06 \\
\hline $\begin{array}{l}\text { CBSAor- } \\
\text { Div_29420 }\end{array}$ & 0.06817860 & 1.87 & 0.06565440 & 1.80 \\
\hline $\begin{array}{l}\text { CBSAor- } \\
\text { Div_29460 }\end{array}$ & 0.00284040 & 0.10 & 0.00354550 & 0.12 \\
\hline $\begin{array}{l}\text { CBSAor- } \\
\text { Div_29540 }\end{array}$ & 0.10624550 & 2.08 & 0.10737370 & 2.10 \\
\hline $\begin{array}{l}\text { CBSAor- } \\
\text { Div_29620 }\end{array}$ & -0.01207380 & -0.29 & -0.00990320 & -0.24 \\
\hline $\begin{array}{l}\text { CBSAor- } \\
\text { Div_29740 }\end{array}$ & -0.00684160 & -0.10 & -0.00546660 & -0.08 \\
\hline $\begin{array}{l}\text { CBSAor- } \\
\text { Div_29820 }\end{array}$ & 0.00649660 & 0.30 & 0.00695230 & 0.32 \\
\hline
\end{tabular}

\begin{tabular}{lllll}
\hline Dummy vari- & Coefficient (1) & $t$-stat (1) Coefficient (2) & $t$-stat (2)
\end{tabular} able

\begin{tabular}{|c|c|c|c|c|}
\hline $\begin{array}{l}\text { CBSAor- } \\
\text { Div_29940 }\end{array}$ & 0.05458880 & 0.80 & 0.05768350 & 0.85 \\
\hline $\begin{array}{l}\text { CBSAor- } \\
\text { Div_30140 }\end{array}$ & 0.0192 & 0.46 & 0.01708390 & 0.41 \\
\hline $\begin{array}{l}\text { CBSAor- } \\
\text { Div_30220 }\end{array}$ & 0.106 & 3.32 & 0.10533770 & 3.28 \\
\hline $\begin{array}{l}\text { CBSAor- } \\
\text { Div_30380 }\end{array}$ & -0.10034160 & -1.44 & -0.10199680 & -1.46 \\
\hline $\begin{array}{l}\text { CBSAor- } \\
\text { Div_30460 }\end{array}$ & -0.01952060 & -0.67 & -0.01839540 & -0.64 \\
\hline $\begin{array}{l}\text { CBSAor- } \\
\text { Div_30620 }\end{array}$ & -0.30745730 & -4.62 & -0.30630890 & -4.60 \\
\hline $\begin{array}{l}\text { CBSAor- } \\
\text { Div_30780 }\end{array}$ & -0.09934910 & -3.24 & -0.09773410 & -3.19 \\
\hline $\begin{array}{l}\text { CBSAor- } \\
\text { Div_30980 }\end{array}$ & -0.12101020 & -1.59 & -0.11960550 & -1.58 \\
\hline $\begin{array}{l}\text { CBSAor- } \\
\text { Div_31084 }\end{array}$ & 0.07912780 & 3.75 & 0.07865070 & 3.73 \\
\hline $\begin{array}{l}\text { CBSAor- } \\
\text { Div_31140 }\end{array}$ & 0.04458550 & 2.01 & 0.04178470 & 1.88 \\
\hline $\begin{array}{l}\text { CBSAor- } \\
\text { Div_31340 }\end{array}$ & -0.16127920 & -1.13 & -0.16062280 & -1.13 \\
\hline $\begin{array}{l}\text { CBSAor- } \\
\text { Div_31420 }\end{array}$ & 19560 & -3.36 & -0.15389440 & -3.33 \\
\hline $\begin{array}{l}\text { CBSAor- } \\
\text { Div_31460 }\end{array}$ & 0.02559110 & 0.37 & 0.02665190 & 0.38 \\
\hline $\begin{array}{l}\text { CBSAor- } \\
\text { Div_31540 }\end{array}$ & -0.02551110 & -0.44 & -0.02343280 & -0.41 \\
\hline $\begin{array}{l}\text { CBSAor- } \\
\text { Div_31700 }\end{array}$ & -0.02743750 & -1.05 & -0.02731570 & -1.05 \\
\hline $\begin{array}{l}\text { CBSAor- } \\
\text { Div_31740 }\end{array}$ & -0.03926970 & -0.86 & -0.03718140 & -0.82 \\
\hline $\begin{array}{l}\text { CBSAor- } \\
\text { Div_31820 }\end{array}$ & -0.15683640 & -2.25 & -0.15676860 & -2.25 \\
\hline $\begin{array}{l}\text { CBSAor- } \\
\text { Div_32180 }\end{array}$ & -0.01673650 & -0.27 & -0.01575960 & -0.26 \\
\hline $\begin{array}{l}\text { CBSAor- } \\
\text { Div_32580 }\end{array}$ & -0.05165460 & -1.57 & -0.05359980 & -1.63 \\
\hline $\begin{array}{l}\text { CBSAor- } \\
\text { Div_32780 }\end{array}$ & -0.03747760 & -0.49 & -0.03677210 & -0.48 \\
\hline $\begin{array}{l}\text { CBSAor- } \\
\text { Div_32820 }\end{array}$ & -0.02190720 & -1.01 & -0.02255240 & -1.04 \\
\hline $\begin{array}{l}\text { CBSAor- } \\
\text { Div_32860 }\end{array}$ & -0.2 & -2.79 & -0.25770190 & -2.81 \\
\hline $\begin{array}{l}\text { CBSAor- } \\
\text { Div_33124 }\end{array}$ & 0.06046110 & 2.83 & 0.06050180 & 2.83 \\
\hline $\begin{array}{l}\text { CBSAor- } \\
\text { Div_33340 }\end{array}$ & -0.02754650 & -1.19 & -0.02707490 & -1.17 \\
\hline $\begin{array}{l}\text { CBSAor- } \\
\text { Div_33460 }\end{array}$ & -0.00195530 & -0.09 & -0.00159080 & -0.07 \\
\hline $\begin{array}{l}\text { CBSAor- } \\
\text { Div_33500 }\end{array}$ & 0.14269180 & 0.71 & 0.14347310 & 0.71 \\
\hline $\begin{array}{l}\text { CBSAor- } \\
\text { Div_33660 }\end{array}$ & -0.04282600 & -0.82 & -0.04176980 & -0.80 \\
\hline
\end{tabular}


$\overline{\text { Dummy vari- } \quad \text { Coefficient (1) } \quad t \text {-stat (1) Coefficient (2) } t \text {-stat (2) }}$ able

\begin{tabular}{|c|c|c|c|c|}
\hline $\begin{array}{l}\text { CBSAor- } \\
\text { Div_33700 }\end{array}$ & 0.06599780 & 0.84 & 0.06370190 & 0.81 \\
\hline $\begin{array}{l}\text { CBSAor- } \\
\text { Div_33860 }\end{array}$ & -0.16933260 & -2.36 & -0.16615040 & -2.32 \\
\hline $\begin{array}{l}\text { CBSAor- } \\
\text { Div_33874 }\end{array}$ & 0.00843120 & 0.39 & 0.01025840 & 0.47 \\
\hline $\begin{array}{l}\text { CBSAor- } \\
\text { Div_34100 }\end{array}$ & -0.18511220 & -4.77 & -0.18291590 & -4.72 \\
\hline $\begin{array}{l}\text { CBSAor- } \\
\text { Div_34340 }\end{array}$ & 0.22491730 & 3.60 & 0.22584830 & 3.61 \\
\hline $\begin{array}{l}\text { CBSAor- } \\
\text { Div_34820 }\end{array}$ & 0.00598390 & 0.15 & 0.00723470 & 0.18 \\
\hline $\begin{array}{l}\text { CBSAor- } \\
\text { Div_34900 }\end{array}$ & 0.12034050 & 3.87 & 0.12212600 & 3.92 \\
\hline $\begin{array}{l}\text { CBSAor- } \\
\text { Div_34940 }\end{array}$ & 0.05034720 & 1.99 & 0.05212590 & 2.06 \\
\hline $\begin{array}{l}\text { CBSAor- } \\
\text { Div_34980 }\end{array}$ & 0.06662420 & 3.05 & 0.06761180 & 3.10 \\
\hline $\begin{array}{l}\text { CBSAor- } \\
\text { Div_35004 }\end{array}$ & -0.03031980 & -1.27 & -0.02831350 & -1.19 \\
\hline $\begin{array}{l}\text { CBSAor- } \\
\text { Div_35084 }\end{array}$ & -0.02038860 & -0.94 & -0.01884520 & -0.87 \\
\hline $\begin{array}{l}\text { CBSAor- } \\
\text { Div_35300 }\end{array}$ & -0.07603710 & -2.64 & -0.07457310 & -2.59 \\
\hline $\begin{array}{l}\text { CBSAor- } \\
\text { Div_35380 }\end{array}$ & -0.02589330 & -0.94 & -0.02150100 & -0.78 \\
\hline $\begin{array}{l}\text { CBSAor- } \\
\text { Div_35440 }\end{array}$ & -0.05464280 & -0.27 & -0.05515830 & -0.27 \\
\hline $\begin{array}{l}\text { CBSAor- } \\
\text { Div_35614 }\end{array}$ & 0.05540560 & 2.62 & 0.05606180 & 2.65 \\
\hline $\begin{array}{l}\text { CBSAor- } \\
\text { Div_35660 }\end{array}$ & -0.30360780 & -1.85 & -0.30170010 & -1.84 \\
\hline $\begin{array}{l}\text { CBSAor- } \\
\text { Div_35840 }\end{array}$ & -0.13614880 & -4.15 & -0.13530930 & -4.13 \\
\hline $\begin{array}{l}\text { CBSAor- } \\
\text { Div_35980 }\end{array}$ & -0.06334620 & -1.23 & -0.06059340 & -1.18 \\
\hline $\begin{array}{l}\text { CBSAor- } \\
\text { Div_36084 }\end{array}$ & 0.07295630 & 3.44 & 0.07284420 & 3.43 \\
\hline $\begin{array}{l}\text { CBSAor- } \\
\text { Div_36100 }\end{array}$ & -0.08267180 & -1.85 & -0.08121240 & -1.81 \\
\hline $\begin{array}{l}\text { CBSAor- } \\
\text { Div_36220 }\end{array}$ & 0.23365600 & 2.55 & 0.23478740 & 2.56 \\
\hline $\begin{array}{l}\text { CBSAor- } \\
\text { Div_36260 }\end{array}$ & 0.13148810 & 2.64 & 0.13272350 & 2.66 \\
\hline $\begin{array}{l}\text { CBSAor- } \\
\text { Div_36420 }\end{array}$ & -0.01986660 & -0.81 & -0.02063800 & -0.84 \\
\hline $\begin{array}{l}\text { CBSAor- } \\
\text { Div_36500 }\end{array}$ & 0.06639780 & 2.04 & 0.06411760 & 1.97 \\
\hline $\begin{array}{l}\text { CBSAor- } \\
\text { Div_36540 }\end{array}$ & 0.00694950 & 0.27 & 0.00835070 & 0.32 \\
\hline $\begin{array}{l}\text { CBSAor- } \\
\text { Div_36740 }\end{array}$ & 0.03364750 & 1.57 & 0.03475590 & 1.62 \\
\hline $\begin{array}{l}\text { CBSAor- } \\
\text { Div_36900 }\end{array}$ & -0.13957460 & -2.00 & -0.13741170 & -1.97 \\
\hline
\end{tabular}

Dummy vari- Coefficient (1) $t$-stat (1) Coefficient (2) $t$-stat (2) able

\begin{tabular}{|c|c|c|c|c|}
\hline $\begin{array}{l}\text { CBSAor- } \\
\text { Div_36980 }\end{array}$ & -0.21518380 & -2.65 & -0.21478830 & -2.65 \\
\hline $\begin{array}{l}\text { CBSAor- } \\
\text { Div_37060 }\end{array}$ & -0.53151670 & -3.72 & -0.52562270 & -3.68 \\
\hline $\begin{array}{l}\text { CBSAor- } \\
\text { Div_37100 }\end{array}$ & 0.03864310 & 1.65 & 0.04008420 & 1.71 \\
\hline $\begin{array}{l}\text { CBSAor- } \\
\text { Div_37120 }\end{array}$ & -0.11348630 & -1.63 & -0.11240190 & -1.61 \\
\hline $\begin{array}{l}\text { CBSAor- } \\
\text { Div_37140 }\end{array}$ & -0.01232990 & -0.29 & -0.01116930 & -0.26 \\
\hline $\begin{array}{l}\text { CBSAor- } \\
\text { Div_37220 }\end{array}$ & 0.14153230 & 2.08 & 0.14017350 & 2.06 \\
\hline $\begin{array}{l}\text { CBSAor- } \\
\text { Div_37340 }\end{array}$ & -0.02969700 & -1.09 & -0.02812320 & -1.03 \\
\hline $\begin{array}{l}\text { CBSAor- } \\
\text { Div_37460 }\end{array}$ & -0.29366090 & -2.51 & -0.29293500 & -2.50 \\
\hline $\begin{array}{l}\text { CBSAor- } \\
\text { Div_37660 }\end{array}$ & 0.02285230 & 0.37 & 0.02383950 & 0.39 \\
\hline $\begin{array}{l}\text { CBSAor- } \\
\text { Div_37860 }\end{array}$ & 0.08406940 & 2.24 & 0.08423190 & 2.24 \\
\hline $\begin{array}{l}\text { CBSAor- } \\
\text { Div_37900 }\end{array}$ & -0.11660080 & -3.26 & -0.11566810 & -3.23 \\
\hline $\begin{array}{l}\text { CBSAor- } \\
\text { Div_37964 }\end{array}$ & 0.01040860 & 0.46 & 0.01181320 & 0.53 \\
\hline $\begin{array}{l}\text { CBSAor- } \\
\text { Div_38060 }\end{array}$ & 0.02744490 & 1.29 & 0.02833760 & 1.34 \\
\hline $\begin{array}{l}\text { CBSAor- } \\
\text { Div_38240 }\end{array}$ & -0.03190040 & -0.31 & -0.02985990 & -0.29 \\
\hline $\begin{array}{l}\text { CBSAor- } \\
\text { Div_38300 }\end{array}$ & -0.02643720 & -1.15 & -0.02429790 & -1.06 \\
\hline $\begin{array}{l}\text { CBSAor- } \\
\text { Div_38820 }\end{array}$ & 0.09858810 & 1.72 & 0.10062660 & 1.75 \\
\hline $\begin{array}{l}\text { CBSAor- } \\
\text { Div_38860 }\end{array}$ & -0.01334860 & -0.45 & -0.01174550 & -0.40 \\
\hline $\begin{array}{l}\text { CBSAor- } \\
\text { Div_38900 }\end{array}$ & 0.06889040 & 3.23 & 0.06846580 & 3.21 \\
\hline $\begin{array}{l}\text { CBSAor- } \\
\text { Div_38940 }\end{array}$ & 0.01473850 & 0.56 & 0.01657220 & 0.63 \\
\hline $\begin{array}{l}\text { CBSAor- } \\
\text { Div_39300 }\end{array}$ & -0.00619740 & -0.27 & -0.00605800 & -0.27 \\
\hline $\begin{array}{l}\text { CBSAor- } \\
\text { Div_39340 }\end{array}$ & 0.09389480 & 1.53 & 0.09138870 & 1.49 \\
\hline $\begin{array}{l}\text { CBSAor- } \\
\text { Div_39460 }\end{array}$ & 0.04489030 & 1.35 & 0.04709460 & 1.42 \\
\hline $\begin{array}{l}\text { CBSAor- } \\
\text { Div_39540 }\end{array}$ & -0.01156810 & -0.30 & -0.01200960 & -0.32 \\
\hline $\begin{array}{l}\text { CBSAor- } \\
\text { Div_39580 }\end{array}$ & -0.00042240 & -0.02 & 0.00169160 & 0.08 \\
\hline $\begin{array}{l}\text { CBSAor- } \\
\text { Div_39660 }\end{array}$ & -0.02593890 & -0.33 & -0.02474270 & -0.32 \\
\hline $\begin{array}{l}\text { CBSAor- } \\
\text { Div_39740 }\end{array}$ & 0.02341580 & 0.74 & 0.02122360 & 0.67 \\
\hline $\begin{array}{l}\text { CBSAor- } \\
\text { Div_39900 }\end{array}$ & 0.03551000 & 1.58 & 0.03544870 & 1.58 \\
\hline
\end{tabular}




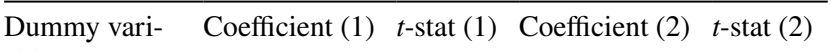
able

\begin{tabular}{|c|c|c|c|c|}
\hline $\begin{array}{l}\text { CBSAor- } \\
\text { Div_39980 }\end{array}$ & -0.48142420 & -5.25 & -0.48094810 & -5 \\
\hline $\begin{array}{l}\text { CBSAor- } \\
\text { Div_40060 }\end{array}$ & -0.00960210 & -0.42 & -0.00962380 & - \\
\hline $\begin{array}{l}\text { CBSAor- } \\
\text { Div_40140 }\end{array}$ & 0.10623210 & 5.01 & 0.10475170 & \\
\hline $\begin{array}{l}\text { CBSAor- } \\
\text { Div_40220 }\end{array}$ & 0.06354130 & 1.02 & 0.06073260 & \\
\hline $\begin{array}{l}\text { CBSAor- } \\
\text { Div_40300 }\end{array}$ & 0.00437450 & 0.10 & 0.00145920 & \\
\hline $\begin{array}{l}\text { CBSAor- } \\
\text { Div_40380 }\end{array}$ & 0.01717140 & 0.30 & 0.01816500 & \\
\hline $\begin{array}{l}\text { CBSAor- } \\
\text { Div_40420 }\end{array}$ & -0.03750120 & -0.81 & -0.03664120 & - \\
\hline $\begin{array}{l}\text { CBSAor- } \\
\text { Div_40484 }\end{array}$ & 0.09052400 & 3.39 & 0.09240800 & \\
\hline $\begin{array}{l}\text { CBSAor- } \\
\text { Div_40900 }\end{array}$ & -0.00975770 & -0.45 & -0.00825920 & - \\
\hline $\begin{array}{l}\text { CBSAor- } \\
\text { Div_41060 }\end{array}$ & 0.01050490 & 0.16 & 0.01076980 & \\
\hline $\begin{array}{l}\text { CBSAor- } \\
\text { Div_41180 }\end{array}$ & 0.00504310 & 0.23 & 0.00521270 & \\
\hline $\begin{array}{l}\text { CBSAor- } \\
\text { Div_41420 }\end{array}$ & 0.02857930 & 0.20 & 0.02940910 & \\
\hline $\begin{array}{l}\text { CBSAor- } \\
\text { Div_41460 }\end{array}$ & 0.05863430 & 1.46 & 0.06020630 & \\
\hline $\begin{array}{l}\text { CBSAor- } \\
\text { Div_41500 }\end{array}$ & 0.01377610 & 0.41 & 0.01530860 & \\
\hline $\begin{array}{l}\text { CBSAor- } \\
\text { Div_41540 }\end{array}$ & -0.13790690 & -2.02 & -0.13519050 & -1 \\
\hline $\begin{array}{l}\text { CBSAor- } \\
\text { Div_41620 }\end{array}$ & 0.03160430 & 1.41 & 0.03267340 & \\
\hline $\begin{array}{l}\text { CBSAor- } \\
\text { Div_41700 }\end{array}$ & 0.01377140 & 0.63 & 0.01416410 & \\
\hline $\begin{array}{l}\text { CBSAor- } \\
\text { Div_41740 }\end{array}$ & 0.05250510 & 2.47 & 0.05335130 & \\
\hline $\begin{array}{l}\text { CBSAor- } \\
\text { Div_41884 }\end{array}$ & 0.09862270 & 4.61 & 0.10050470 & \\
\hline $\begin{array}{l}\text { CBSAor- } \\
\text { Div_41940 }\end{array}$ & 0.05760110 & 2.70 & 0.05777720 & \\
\hline $\begin{array}{l}\text { CBSAor- } \\
\text { Div_42020 }\end{array}$ & 0.03042880 & 1.00 & 0.03198710 & \\
\hline $\begin{array}{l}\text { CBSAor- } \\
\text { Div_42034 }\end{array}$ & 0.08786340 & 3.74 & 0.09058530 & \\
\hline $\begin{array}{l}\text { CBSAor- } \\
\text { Div_42100 }\end{array}$ & 0.02538300 & 0.62 & 0.02660410 & \\
\hline $\begin{array}{l}\text { CBSAor- } \\
\text { Div_42140 }\end{array}$ & 0.03980890 & 1.39 & 0.04228720 & \\
\hline $\begin{array}{l}\text { CBSAor- } \\
\text { Div_42200 }\end{array}$ & 0.03147910 & 1.16 & 0.03228720 & \\
\hline $\begin{array}{l}\text { CBSAor- } \\
\text { Div_42220 }\end{array}$ & 0.08286040 & 3.16 & 0.08476810 & \\
\hline $\begin{array}{l}\text { CBSAor- } \\
\text { Div_42340 }\end{array}$ & -0.04732210 & -1.11 & -0.04610870 & - \\
\hline
\end{tabular}

\begin{tabular}{lllll}
\hline Dummy vari- & Coefficient (1) & $t$-stat (1) Coefficient (2) & $t$-stat (2)
\end{tabular} able

\begin{tabular}{|c|c|c|c|c|}
\hline $\begin{array}{l}\text { CBSAor- } \\
\text { Div_42540 }\end{array}$ & -0.10999160 & -2.95 & -0.11161480 & -2.99 \\
\hline $\begin{array}{l}\text { CBSAor- } \\
\text { Div_42644 }\end{array}$ & 0.08228880 & 3.89 & 0.08265010 & 3.91 \\
\hline $\begin{array}{l}\text { CBSAor- } \\
\text { Div_42680 }\end{array}$ & 0.11826030 & 1.51 & 0.12133860 & 1.55 \\
\hline $\begin{array}{l}\text { CBSAor- } \\
\text { Div_43100 }\end{array}$ & 0.21379830 & 3.28 & 0.21204220 & 3.26 \\
\hline $\begin{array}{l}\text { CBSAor- } \\
\text { Div_43140 }\end{array}$ & -0.21161600 & -2.51 & -0.21120770 & -2.51 \\
\hline $\begin{array}{l}\text { CBSAor- } \\
\text { Div_43300 }\end{array}$ & 0.00902390 & 0.22 & 0.01025660 & 0.25 \\
\hline $\begin{array}{l}\text { CBSAor- } \\
\text { Div_43340 }\end{array}$ & -0.09569160 & -1.64 & -0.09671040 & -1.66 \\
\hline $\begin{array}{l}\text { CBSAor- } \\
\text { Div_43524 }\end{array}$ & 0.01170800 & 0.54 & 0.01398840 & 0.65 \\
\hline $\begin{array}{l}\text { CBSAor- } \\
\text { Div_43580 }\end{array}$ & 0.04961740 & 0.63 & 0.05082830 & 0.65 \\
\hline $\begin{array}{l}\text { CBSAor- } \\
\text { Div_43620 }\end{array}$ & 0.05420990 & 0.90 & 0.05518720 & 0.92 \\
\hline $\begin{array}{l}\text { CBSAor- } \\
\text { Div_43780 }\end{array}$ & -0.09273170 & -2.32 & -0.09252370 & -2.32 \\
\hline $\begin{array}{l}\text { CBSAor- } \\
\text { Div_43900 }\end{array}$ & 0.05813520 & 1.18 & 0.05538620 & 1.12 \\
\hline $\begin{array}{l}\text { CBSAor- } \\
\text { Div_44060 }\end{array}$ & 0.18025260 & 3.90 & 0.17755230 & 3.84 \\
\hline $\begin{array}{l}\text { CBSAor- } \\
\text { Div_44140 }\end{array}$ & -0.21345020 & -4.91 & -0.21152660 & -4.86 \\
\hline $\begin{array}{l}\text { CBSAor- } \\
\text { Div_44180 }\end{array}$ & 0.23211850 & 2.96 & 0.23327410 & 2.97 \\
\hline $\begin{array}{l}\text { CBSAor- } \\
\text { Div_44260 }\end{array}$ & -0.04012310 & -0.49 & -0.03696890 & -0.46 \\
\hline $\begin{array}{l}\text { CBSAor- } \\
\text { Div_44340 }\end{array}$ & -0.52972930 & -4.14 & -0.52914840 & -4.13 \\
\hline $\begin{array}{l}\text { CBSAor- } \\
\text { Div_44420 }\end{array}$ & -0.09630910 & -1.80 & -0.09502500 & -1.78 \\
\hline $\begin{array}{l}\text { CBSAor- } \\
\text { Div_44700 }\end{array}$ & 0.07183550 & 2.95 & 0.06971310 & 2.87 \\
\hline $\begin{array}{l}\text { CBSAor- } \\
\text { Div_45060 }\end{array}$ & -0.14841490 & -1.89 & -0.15292740 & -1.95 \\
\hline $\begin{array}{l}\text { CBSAor- } \\
\text { Div_45104 }\end{array}$ & 0.12466630 & 5.53 & 0.12220060 & 5.42 \\
\hline $\begin{array}{l}\text { CBSAor- } \\
\text { Div_45220 }\end{array}$ & 0.02607360 & 0.85 & 0.02820450 & 0.92 \\
\hline $\begin{array}{l}\text { CBSAor- } \\
\text { Div_45300 }\end{array}$ & 0.02279310 & 1.06 & 0.02464630 & 1.14 \\
\hline $\begin{array}{l}\text { CBSAor- } \\
\text { Div_45460 }\end{array}$ & -0.10874780 & -1.39 & -0.10776200 & -1.38 \\
\hline $\begin{array}{l}\text { CBSAor- } \\
\text { Div_45500 }\end{array}$ & -0.06602140 & -1.03 & -0.06474480 & -1.02 \\
\hline $\begin{array}{l}\text { CBSAor- } \\
\text { Div_45520 }\end{array}$ & 0.82549570 & 12.67 & 0.82661550 & 12.69 \\
\hline $\begin{array}{l}\text { CBSAor- } \\
\text { Div_45540 }\end{array}$ & 0.09185280 & 1.13 & 0.09509510 & 1.17 \\
\hline
\end{tabular}


Dummy vari- Coefficient (1) $t$-stat (1) Coefficient (2) $t$-stat (2) able

\begin{tabular}{|c|c|c|c|c|}
\hline $\begin{array}{l}\text { CBSAor- } \\
\text { Div_45780 }\end{array}$ & -0.00891690 & -0.24 & -0.00777810 & -0.21 \\
\hline $\begin{array}{l}\text { CBSAor- } \\
\text { Div_45820 }\end{array}$ & -0.01729470 & -0.37 & -0.01296280 & -0.28 \\
\hline $\begin{array}{l}\text { CBSAor- } \\
\text { Div_45860 }\end{array}$ & 0.07847140 & 0.67 & 0.07881730 & 0.67 \\
\hline $\begin{array}{l}\text { CBSAor- } \\
\text { Div_45940 }\end{array}$ & 0.06496440 & 2.68 & 0.06584670 & 2.72 \\
\hline $\begin{array}{l}\text { CBSAor- } \\
\text { Div_46020 }\end{array}$ & 0.08125420 & 2.32 & 0.08287790 & 2.36 \\
\hline $\begin{array}{l}\text { CBSAor- } \\
\text { Div_46060 }\end{array}$ & -0.02807500 & -1.06 & -0.02755890 & -1.04 \\
\hline $\begin{array}{l}\text { CBSAor- } \\
\text { Div_46140 }\end{array}$ & -0.00146830 & -0.06 & -0.00080000 & -0.03 \\
\hline $\begin{array}{l}\text { CBSAor- } \\
\text { Div_46180 }\end{array}$ & -0.08106300 & -0.92 & -0.07972340 & -0.91 \\
\hline $\begin{array}{l}\text { CBSAor- } \\
\text { Div_46220 }\end{array}$ & -0.00033170 & -0.01 & 0.00064310 & 0.01 \\
\hline $\begin{array}{l}\text { CBSAor- } \\
\text { Div_46300 }\end{array}$ & 0.07008260 & 1.16 & 0.07127200 & 1.18 \\
\hline $\begin{array}{l}\text { CBSAor- } \\
\text { Div_46500 }\end{array}$ & -0.54376900 & -5.93 & -0.54250340 & -5.91 \\
\hline $\begin{array}{l}\text { CBSAor- } \\
\text { Div_46520 }\end{array}$ & -0.02806810 & -1.04 & -0.02612630 & -0.97 \\
\hline $\begin{array}{l}\text { CBSAor- } \\
\text { Div_46540 }\end{array}$ & 0.12283970 & 1.96 & 0.12013270 & 1.92 \\
\hline $\begin{array}{l}\text { CBSAor- } \\
\text { Div_46660 }\end{array}$ & -0.15036310 & -1.98 & -0.14980330 & -1.97 \\
\hline $\begin{array}{l}\text { CBSAor- } \\
\text { Div_46700 }\end{array}$ & 0.04154590 & 1.63 & 0.04094140 & 1.61 \\
\hline $\begin{array}{l}\text { CBSAor- } \\
\text { Div_46740 }\end{array}$ & -0.06045500 & -1.30 & -0.05847260 & -1.25 \\
\hline $\begin{array}{l}\text { CBSAor- } \\
\text { Div_47260 }\end{array}$ & 0.00116330 & 0.05 & 0.00308160 & 0.13 \\
\hline $\begin{array}{l}\text { CBSAor- } \\
\text { Div_47300 }\end{array}$ & 0.37252660 & 5.95 & 0.37317330 & 5.97 \\
\hline $\begin{array}{l}\text { CBSAor- } \\
\text { Div_47664 }\end{array}$ & -0.04284580 & -1.91 & -0.04112840 & -1.83 \\
\hline $\begin{array}{l}\text { CBSAor- } \\
\text { Div_47894 }\end{array}$ & 0.03246550 & 1.54 & 0.03463630 & 1.64 \\
\hline $\begin{array}{l}\text { CBSAor- } \\
\text { Div_47940 }\end{array}$ & -0.04156440 & -0.95 & -0.04086620 & -0.93 \\
\hline $\begin{array}{l}\text { CBSAor- } \\
\text { Div_48424 }\end{array}$ & 0.03875110 & 1.80 & 0.04052880 & 1.88 \\
\hline $\begin{array}{l}\text { CBSAor- } \\
\text { Div_48620 }\end{array}$ & -0.03747680 & -0.70 & -0.03823650 & -0.72 \\
\hline $\begin{array}{l}\text { CBSAor- } \\
\text { Div_48660 }\end{array}$ & 0.05614910 & 1.22 & 0.05692420 & 1.24 \\
\hline $\begin{array}{l}\text { CBSAor- } \\
\text { Div_48780 }\end{array}$ & -0.49116150 & -6.85 & -0.49072090 & -6.85 \\
\hline $\begin{array}{l}\text { CBSAor- } \\
\text { Div_48864 }\end{array}$ & -0.01527400 & -0.64 & -0.01637680 & -0.68 \\
\hline $\begin{array}{l}\text { CBSAor- } \\
\text { Div_48900 }\end{array}$ & 0.01675230 & 0.39 & 0.01937340 & 0.45 \\
\hline
\end{tabular}

Dummy vari- Coefficient (1) $t$-stat (1) Coefficient (2) $t$-stat (2) able

\begin{tabular}{lrrrr}
\hline CBSAor- & -0.38295830 & -4.17 & -0.38173280 & -4.16 \\
Div_48940 & & & & \\
CBSAor- & 0.06046340 & 1.04 & 0.06273630 & 1.08 \\
$\quad$ Div_49020 & & & & \\
CBSAor- & -0.09769220 & -2.13 & -0.09654470 & -2.11 \\
$\quad$ Div_49180 & & & & \\
CBSAor- & -0.02457440 & -1.03 & -0.02524680 & -1.06 \\
$\quad$ Div_49340 & & & & \\
CBSAor- & -0.03406850 & -0.89 & -0.03230780 & -0.84 \\
$\quad$ Div_49420 & & & & \\
CBSAor- & -0.08854540 & -2.06 & -0.08782240 & -2.05 \\
$\quad$ Div_49620 & & & & \\
CBSAor- & 0.00583120 & 0.09 & 0.00682860 & 0.11 \\
$\quad$ Div_49700 & & & & \\
CBSAor- & 0.13135090 & 1.73 & 0.13219290 & 1.74 \\
Div_49740 & & & & \\
CBSAor- & -0.10569670 & -1.87 & -0.10385900 & -1.84 \\
Div_49780 & & & & \\
\hline
\end{tabular}

Open Access This article is licensed under a Creative Commons Attribution 4.0 International License, which permits use, sharing, adaptation, distribution and reproduction in any medium or format, as long as you give appropriate credit to the original author(s) and the source, provide a link to the Creative Commons licence, and indicate if changes were made. The images or other third party material in this article are included in the article's Creative Commons licence, unless indicated otherwise in a credit line to the material. If material is not included in the article's Creative Commons licence and your intended use is not permitted by statutory regulation or exceeds the permitted use, you will need to obtain permission directly from the copyright holder. To view a copy of this licence, visit http://creativecommons.org/licenses/by/4.0/.

\section{References}

Bleich, Donald. 2003. The Reaction of Multifamily Capitalization Rates to Natural Disasters. Journal of Real Estate Research 25 (2): 133-144.

Graham, Jr., J. Edward, and William W. Hall, Jr. 2001. Hurricanes, Housing Market Activity, and Coastal Real Estate Values. The Appraisal Journal 69 (4): 379-387.

Graham, Edward, William Hall, and Peter Schuhmann. 2007. Hurricanes, Catastrophic Risk, and Real Estate Market Recovery. Journal of Real Estate Portfolio Management 13 (3): 179-190.

Morgan, Ash. 2007. The Impact of Hurricane Ivan on Expected Flood Losses, Perceived Flood Risk, and Property Values. Journal of Housing Research 16 (1): 47-60.

Salter, Sean P., and Ernest W. King. 2009. Price Adjustment and Liquidity in a Residential Real Estate Market with an Accelerated Information Cascade. Journal of Real Estate Research 31 (4): 421-454.

Simmons, Kevin M., Jamie Brown Kruse, and Douglas A. Smith. 2002. Valuing Mitigation: Real Estate Market Responses to Hurricane 
Loss Reduction Measures. Southern Economic Journal 68 (3): 660-671.

Publisher's Note Springer Nature remains neutral with regard to jurisdictional claims in published maps and institutional affiliations.

Jeffrey D. Fisher Ph.D. is a Professor Emeritus of Real Estate at the Indiana University Kelley School of Business, and a Visiting Professor at Johns Hopkins University. He is the Research and Education Consultant to the National Council of Real Estate Investment Fiduciaries (NCREIF) and President of the Homer Hoyt Institute. He is a member of the advisory committee to the Real Estate Finance and Economics Institute at Ecole hôtelière de Lausanne in Switzerland. Professor Fisher is a coauthor of Real Estate, 9th edition published by John Wiley and Sons, coauthor of Real Estate Finance and Investments, 14th edition, published by McGraw-Hill, and coauthor of Income Property Valuation, published by Dearborn. His books have been translated into Japanese, Korean, and Chinese. Dr. Fisher has published numerous articles in journals such as The Journal of the American Real Estate and Urban Economics Association, Journal of Real Estate Finance and Economics, The Journal of Urban Economics, The Journal of Real Estate Research, Journal of Portfolio Management, National Tax Journal, Public Finance Quarterly, The Appraisal Journal, Real Estate Review, The Real Estate Appraiser and Analyst, Real Estate Issues, The New Corporate Finance, and the Journal of Property Tax Management. Education: Ph.D., Real Estate, Ohio State University; MBA, Wright State University; B.S., Industrial Management, Purdue University.
Sara R. Rutledge Ms. Rutledge is the Founder and Principal Economist of SRR Consulting. She provides expert research and analysis on macroeconomic and real estate topics for a variety of public and private sector clients. Her past and current consulting projects include investment strategy white papers, real estate market research and analysis, and report content creation and management. Ms. Rutledge was previously the Managing Director of Real Estate Products at StratoDem Analytics, an early-stage data science firm delivering market intelligence tools to the real estate industry. She applied her real estate experience in this role to improve and develop UI/UX for to ensure the platform met the research needs of the industry and support clients with incorporation of the platform into their existing research processes. She has also served as the Director of Research for the National Council of Real Estate Investment Fiduciaries (NCREIF), managing all research activities for the private real estate investment management industry association. This work included industry education on quarterly data product releases via a live webinar presentation, in-house reporting, and published articles for Institutional Real Estate Investor. Other previous roles include serving as CBRE's Director of Research and Analysis for Texas, and eight years in North American investment research at Invesco Real Estate. Ms. Rutledge has also taught research methods for the Institute of Applied Economics at the University of North Texas. Ms. Rutledge serves on the ULI Chicago Women's Leadership Initiative (WLI) Advisory Board and is active in the ULI Research Forum and national WLI initiatives. She previously served on the Real Estate Research Institute Advisory Board and National Association for Business Economics (NABE) Board of Directors. For which she remains an active member and committee volunteer. Education: M.S., Applied Economics, University of North Texas; BBA, minor study in Economics and Mathematics, University of North Texas. 